\title{
Long-Term Assessment of Reference Baselines for the Determination of the Crop Water Stress Index in Maize under Mediterranean Conditions
}

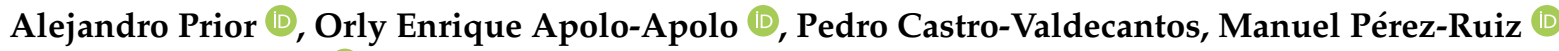 \\ and Gregorio Egea *(D)
}

check for updates

Citation: Prior, A.; Apolo-Apolo, O.E.; Castro-Valdecantos, P.;

Pérez-Ruiz, M.; Egea, G. Long-Term Assessment of Reference Baselines for the Determination of the Crop Water Stress Index in Maize under Mediterranean Conditions. Water 2021, 13, 3119. https://doi.org/ 10.3390/w13213119

Academic Editor: Adriana Bruggeman

Received: 30 September 2021 Accepted: 2 November 2021 Published: 5 November 2021

Publisher's Note: MDPI stays neutral with regard to jurisdictional claims in published maps and institutional affiliations.

Copyright: (c) 2021 by the authors. Licensee MDPI, Basel, Switzerland. This article is an open access article distributed under the terms and conditions of the Creative Commons Attribution (CC BY) license (https:// creativecommons.org/licenses/by/ $4.0 /)$.
Area of Agroforestry Engineering, Technical School of Agricultural Engineering (ETSIA), Universidad de Sevilla, Ctra. Utrera km 1, 41013 Sevilla, Spain; aprior@us.es (A.P.); eapolo@us.es (O.E.A.-A.); pecastro@us.es (P.C.-V.); manuelperez@us.es (M.P.-R.)

* Correspondence: gegea@us.es; Tel.: +34-954481389

\begin{abstract}
Canopy temperature has been proposed as a relevant variable for crop water stress monitoring. Since crop temperature is highly influenced by the prevailing climatic conditions, it is usually normalized with indices such as the crop water stress index (CWSI). The index requires the use of two baselines that relate canopy temperature under maximum stress and non-water stress conditions with vapor pressure deficit (VPD). These reference baselines are specific to each crop and climatic region. In maize, they have been extensively studied for certain climatic regions but very little is known on their suitability to be used under Mediterranean-type conditions nor their temporal stability, both diurnally and between seasons. Thus, the objective of this work was to determine the reference baselines for maize grown under Mediterranean conditions, as well as its diurnal and long-term stability. An experiment was conducted for 3 years in a maize breeding field, under well-watered and water-stressed irrigation treatments. The determined reference baselines for computing CWSI in maize have shown to be stable in the long term but markedly influenced by the meteorological variations between 10-17 h UTC (Coordinated Universal Time). These results indicate that several reference baselines should be used for CWSI computing throughout the abovementioned time interval. The CWSI values calculated for well-watered and water-stressed maize breeding plots using the reference baselines derived in this study were successfully correlated with other physiological indicators of plant water stress.
\end{abstract}

Keywords: CWSI; canopy temperature; corn; infrared thermometry; plant phenotyping

\section{Introduction}

Maize is one of the world's major staple crops [1] and the main cereal grown by smallholder farmers in several regions of the world [2]. The supply of irrigation water is required in many of the producing regions since water deficit has important consequences on maize yield $[3,4]$. However, the limited water resources available for irrigation in many of the producing areas make it necessary to establish deficit irrigation strategies [5] that can compromise the productivity and economy of the farms. Therefore, water stress is an obstacle to the goal of increasing maize production to meet growing food demand in an uncertain climate scenario of increased drought frequency.

Strategies to cope with the scarcity of water resources are mainly focused on monitoring crop water status to optimize production under deficit irrigation strategies [6] and on obtaining more drought-tolerant cultivars in plant-breeding programs [7]. In both cases, crop temperature has been proposed as a reliable tool to monitor maize water status and to identify water stress-tolerant maize genotypes $[6,8,9]$. Despite the sensitivity of leaf temperature to water stress, its absolute value is usually not very informative in terms of crop water status due to the influence that certain climatic variables such as solar radiation, 
vapor pressure deficit or wind speed exert on its value [10]. The development of practical irrigation applications based on crop temperature monitoring has been carried out through thermal indices that normalize its value and allow the quantification of the crop water stress level [6,10-12].

Of the different thermal indices proposed in the literature, the crop water stress index (CWSI) has been the most studied and used for the development of irrigation management protocols in many species [13-17]. Ideally, the CWSI must vary between zero and one; such that zero denotes a fully watered crop and one stands for a total water-stressed status with no water available for crop transpiration.

The CWSI index requires a 'wet' and a 'dry' thermal reference corresponding, respectively, to the temperature of a crop transpiring to its potential rate and that of a crop that does not transpire. These references can be estimated analytically using expressions derived from the crop energy balance equation or using an empirical baseline approach [10,11]. The empirical approach, introduced by Idso et al. [18], determines both thermal references using two reference equations that use the air vapor pressure deficit (VPD) as the independent variable, the so-called non-water stressed (NWSB) and water stressed (WSB) baselines. Although the analytical method has been used by some authors [19,20], the large input requirements of this methodology have hampered its routine use. In any case, the use of more input data in the analytical method does not guarantee greater accuracy of the CWSI as compared to the empirical method [15].

A third alternative for the determination of the CWSI is to directly measure crop temperature $\left(\mathrm{T}_{c}\right)$ together with the temperature of plants transpiring at their potential rate $\left(\mathrm{T}_{p o t}\right)$ and that of non-transpiring plants $\left(\mathrm{T}_{d r y}\right)$. Due to the complexity of having plants in the field transpiring at the potential rate and fully stressed (i.e., non-transpiring) plants, a more practical method is to measure these temperatures on artificial reference surfaces (ARS) that emulate the thermal behavior of the crop under these two extreme water status conditions [8,10,21]. Recently, Apolo-Apolo et al. [8] designed and tested two hemispherical ARSs for $\mathrm{T}_{p o t}$ and $\mathrm{T}_{d r y}$ determination in maize under field conditions. These ARSs were initially conceived for their use in high-throughput phenotyping (HTPP) platforms so that the CWSI can be estimated in real-time in the different plots of maize breeding programs. HTPP platforms usually include $\mathrm{T}_{c}$ among the variables measured [22], but because the time required to take measurements in all the breeding plots can be long, ARS allows $\mathrm{T}_{\text {pot }}$ and $\mathrm{T}_{d r y}$ to be measured at the same time and under the same environmental conditions as $\mathrm{T}_{c}$. In contrast, the reference baselines used to compute CWSI by the empirical method may have been determined for climatic conditions different from those existing when $T_{\mathcal{C}}$ is measured, which may result in inaccurate estimates of the CWSI.

A disadvantage of the ARS developed by Apolo-Apolo et al. [8] for computing the CWSI in maize is that the accurate determination of $\mathrm{T}_{\text {pot }}$ requires solar radiation to be simultaneously measured, increasing the cost and complexity of this methodology as compared to the empirical (i.e., baseline-based) approach for CWSI determination. The implementation of the empirical approach for the determination of CWSI on HTPP platforms is a priori simpler than the use of ARS, but the accuracy of CWSI will be highly conditioned to the temporal stability of the reference baselines, at least during the hourly period in which the measurements are usually performed with HTPPs.

The comparison of the analytical (theoretical) and empirical expressions for CWSI determination shows that the parameters of the empirical NWSB and WSB equations are sensitive to variations in certain climatic variables such as net radiation, wind speed, or the slope of the saturation vapor pressure curve [10]. However, most of the works found in the literature providing reference baselines for the empirical determination of CWSI in maize offer a single equation determined for a certain time interval, usually $3-5 \mathrm{~h}[16,23-26]$. Only the work of Payero and Irmak [27] conducted under humid continental climate conditions offers reference baselines that incorporate the influence of several climatic variables, other than VPD, for their use under varying environmental conditions. The climate of the region where the reference baselines were determined is another aspect to consider since large 
differences in the parameters of the NWSB and WSB equations are frequently observed between the different climatic regions [23,26-28]. In this sense, there are a reasonably high number of experiments conducted in arid and semiarid regions $[16,23,24]$, humid continental regions $[27,29,30]$, and subtropical regions [9,26,31-33], providing reference baselines for CWSI determination in maize. However, only two works provided reference baselines for Mediterranean conditions [28,34], with some inconsistencies, such as the large differences found in the slopes of the NWSB. From this literature review, it is clear that there are still some knowledge gaps regarding the potential of using the empirical approach for the determination of CWSI in maize. Despite the theoretical and empirical evidence of the influence that climatic variables play on NWSB and WSB parameters, most scientific publications present equations that have been obtained for a broad hourly period without having analyzed in detail the influence of diurnal climatic variations on NWSB and WSB. On the other hand, the two studies carried out in the 1990s under Mediterranean climatic conditions showed different results, generating uncertainty as to which reference baselines should be used under these climatic conditions. Obtaining a new set of reference baselines for the calculation of CWSI in a new Mediterranean location does not guarantee that they can be freely used in any area of the Mediterranean region without further testing, as this would require new evaluation trials in different locations. However, this does not detract from the need to conduct further experiments to increase the degree of existing knowledge on the applicability of the empirical method for estimating CWSI in maize.

Based on the above, the objectives of this work are as follows: (i) determine the reference baselines for the empirical calculation of CWSI in maize under Mediterranean climate conditions, (ii) analyze their stability over a wide time interval and in the long term (three years), (iii) evaluate the robustness of the empirical CWSI values determined in a commercial maize breeding program during three crop seasons through their comparison with other crop water status indicators, and (iv) compare empirically determined (i.e., using reference baselines) against ARS-based [8] CWSI values in maize.

\section{Materials and Methods}

\subsection{Experimental Site Description}

The experiment was carried out during the growing seasons of 2017, 2018, and 2019 in a commercial maize breeding field (latitude: $37^{\circ} 27^{\prime} 49.5^{\prime \prime} \mathrm{N}$; longitude: $5^{\circ} 58^{\prime} 41.3^{\prime \prime} \mathrm{W}$; Datum: WGS84) located near Seville (Spain) belonging to the company Corteva Agriscience ${ }^{\mathrm{TM}}$ (Figure 1). The climate of the region is Mediterranean, with an average rainfall and average annual temperature of $565 \mathrm{~mm}$ and $18.5^{\circ} \mathrm{C}$, respectively. The soil is classified as silty clay loam, with field capacity and wilting point values of $0.35 \mathrm{~m}^{3} \mathrm{~m}^{-3}$ and $0.18 \mathrm{~m}^{3} \mathrm{~m}^{-3}$, respectively. Maize cultivars were grown in $6 \mathrm{~m}$ long microplots comprising two rows of maize plants at $0.75 \mathrm{~m} \times 0.17 \mathrm{~m}$ plant spacing. The irrigation system used was drip irrigation, which consisted of $16 \mathrm{~mm}$ diameter polyethylene laterals spaced $0.75 \mathrm{~m}$ apart and $2 \mathrm{~L} \mathrm{~h}^{-1}$ drippers spaced $0.5 \mathrm{~m}$ apart. The experimental field consisted of 120,80 and 326 maize microplots in 2017, 2018, and 2019, respectively, of which a total of 36 microplots were selected for the experiments each year. In 2017 and 2018, 18 plots corresponded to well-watered maize cultivars (WW) and 18 to maize cultivars subjected to water stress during the maturity (i.e., grain filling) period (WS). In 2019, 12 plots corresponded to well-watered maize cultivars, 12 plots to cultivars submitted to flowering stress (WS1), and the remaining 12 plots corresponded to maize cultivars submitted to grain-filling water stress (WS2). The irrigation needs of WW maize cultivars were determined using the FAO-56 crop coefficient approach [35] and irrigation was applied on a daily basis. The water-stressed treatments received $50 \%$ of the irrigation volumes provided to WW, either at the flowering stage (WS1 in 2019) or the maturity period (WS in 2017 and 2018 and WS2 in 2019). Table 1 summarizes some relevant crop developmental stages for the three experimental growing seasons, whereas Table 2 shows the observed rainfall and applied irrigation depths during the three experimental growing seasons. 


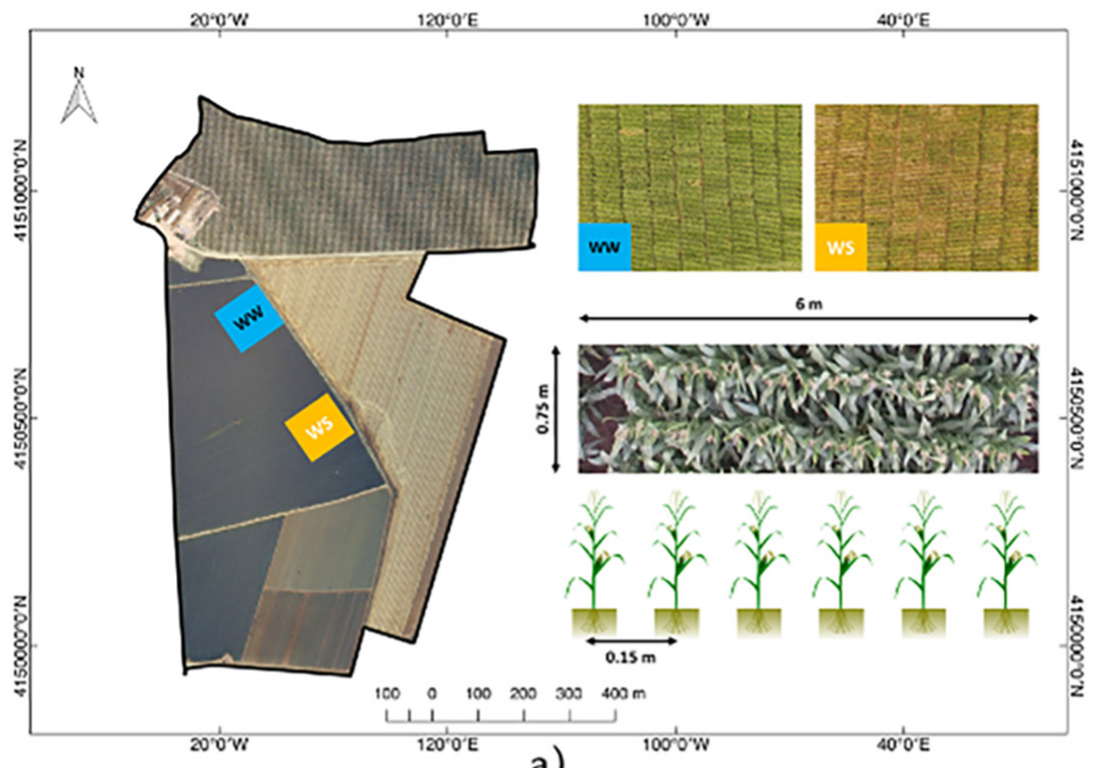

a)

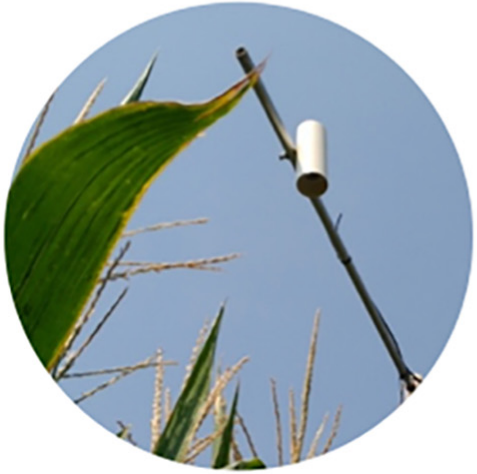

b)

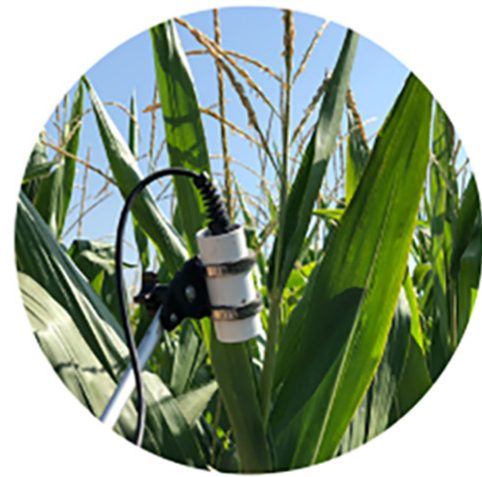

c)

Figure 1. (a) Illustration of the experimental maize breeding field; (b) detail of the infrared thermometer (model IR120, Campbell Scientific Ltd., Shepshed, UK) installed on a well-watered maize plot; (c) detail of the infrared thermometer (model MI-230, Apogee Instruments Ltd., Logan, UT, USA) used for manual $\mathrm{T}_{c}$ measurements.

Table 1. Crop development dates (expressed in days of the year, DOY) during the three experimental growing cycles.

\begin{tabular}{cccc}
\hline Year & Sowing & Flowering & Harvest \\
\hline 2017 & 95 & $190-196$ & 263 \\
2018 & 133 & $161-167$ & 279 \\
2019 & 106 & $168-174$ & 252 \\
\hline
\end{tabular}

Table 2. Rainfall and supplied irrigation depths during the three experimental growing cycles.

\begin{tabular}{ccccc}
\hline Year & Rainfall (mm) & Irrigation Depth $\mathbf{( m m )}$ & & \\
\hline & & WW & WS & \\
2017 & 40 & 711 & 353 & \\
2018 & 49 & 605 & 310 & WS2 \\
& & WW & WS1 & 454 \\
\hline
\end{tabular}




\subsection{Determination of Reference Baselines for Computing the CWSI in Maize under Mediterranean-Type Conditions}

Two infrared thermometers (IRTs) (model IR120, Campbell Scientific Ltd., Shepshed, UK) were mounted over two WW maize plots for DOYs 206 to 217, 207 to 231, and 172 to 211 during the years 2017, 2018, and 2019, respectively. The measurement periods covered the reproductive development stages, except in 2019, which also included the flowering phase. The sensors had an angular field of view of $20^{\circ}$, and the accuracy over the calibrated range was $\pm 0.2^{\circ} \mathrm{C}$. The IRTs were mounted on galvanized steel masts with a horizontal mounting arm (model IR1X0, Campbell Scientific Ltd., Shepshed, UK), ending with a white PVC solar shield (model IR-SS, Campbell Scientific Ltd., Shepshed, UK) to protect the sensor. The IRTs were oriented downward (nadir view), targeting the center of the maize row from a distance of approximately $0.5 \mathrm{~m}$ (Figure 1). The IRTs were connected to a datalogger (model CR1000, Campbell Scientific Ltd., Shepshed, UK), which recorded the canopy temperatures $\left(\mathrm{T}_{c}\right)$ every $10 \mathrm{~min}$. Only $\mathrm{T}_{c}$ measurements from clear-sky (cloudless) days were used to derive the reference baselines defined in Section 2.4 for CWSI calculation. The clear-sky days were selected by comparing measured ground-level solar radiation values against estimated clear-sky solar radiation values. Estimation of clear-sky solar radiation values was performed following the procedure described in [35]. The $\mathrm{T}_{c}$ data measured during the hourly period 10:00-17:00 $\mathrm{h}$ UTC were used to determine the reference baselines. The required climatic variables were obtained from an agroclimatic station of the Andalusian government placed near the experimental field (latitude: $37^{\circ} 27^{\prime} 24^{\prime \prime} \mathrm{N}$; longitude: $05^{\circ} 55^{\prime} 29^{\prime \prime}$ W; Datum: WGS84). Table 3 summarizes the prevailing climatic variables during the three experimental periods used to derive the reference baselines.

Table 3. Hourly mean climatic conditions over the periods (expressed in days of the year, DOY) 206-217 (2017), 207-231 (2018) and 172-211 (2019). $\mathrm{T}_{a}$ : air temperature, RH: relative humidity, $\mathrm{u}$ : wind speed, $\mathrm{R}_{S}$ : solar radiation, VPD: vapor pressure deficit.

\begin{tabular}{|c|c|c|c|c|c|c|}
\hline UTC & Year & $\mathrm{T}_{a}\left({ }^{\circ} \mathrm{C}\right)$ & RH (\%) & $\mathrm{u}\left(\mathrm{m} \mathrm{s}^{-1}\right)$ & $\mathrm{R}_{s}\left(\mathrm{~W} \mathrm{~m}^{-2}\right)$ & VPD (kPa) \\
\hline & 2017 & 30.4 & 43.1 & 0.9 & 748 & 2.6 \\
\hline \multirow[t]{3}{*}{10} & 2018 & 29.0 & 46.0 & 1.6 & 729 & 2.3 \\
\hline & 2019 & 26.5 & 53.0 & 1.1 & 750 & 1.7 \\
\hline & 2017 & 32.1 & 41.0 & 1.1 & 841 & 2.9 \\
\hline \multirow[t]{3}{*}{11} & 2018 & 30.8 & 40.8 & 1.8 & 843 & 2.8 \\
\hline & 2019 & 28.3 & 47.7 & 1.1 & 866 & 2.1 \\
\hline & 2017 & 33.6 & 38.2 & 1.2 & 891 & 3.3 \\
\hline \multirow[t]{3}{*}{12} & 2018 & 32.5 & 35.6 & 2.0 & 904 & 3.3 \\
\hline & 2019 & 29.8 & 43.8 & 1.1 & 910 & 2.4 \\
\hline & 2017 & 35.0 & 36.3 & 1.5 & 894 & 3.7 \\
\hline \multirow[t]{3}{*}{13} & 2018 & 33.9 & 32.1 & 2.2 & 906 & 3.7 \\
\hline & 2019 & 31.0 & 41.4 & 1.2 & 912 & 2.7 \\
\hline & 2017 & 35.8 & 35.2 & 1.8 & 843 & 3.9 \\
\hline \multirow[t]{3}{*}{14} & 2018 & 35.0 & 28.9 & 2.5 & 851 & 4.1 \\
\hline & 2019 & 31.9 & 39.8 & 1.3 & 864 & 2.9 \\
\hline & 2017 & 36.1 & 34.3 & 2.0 & 738 & 4.0 \\
\hline \multirow[t]{3}{*}{15} & 2018 & 35.7 & 27.0 & 2.9 & 740 & 4.4 \\
\hline & 2019 & 32.3 & 38.8 & 1.5 & 761 & 3.0 \\
\hline & 2017 & 35.8 & 33.6 & 2.4 & 594 & 4.0 \\
\hline \multirow[t]{3}{*}{16} & 2018 & 36.1 & 25.5 & 3.3 & 589 & 4.6 \\
\hline & 2019 & 32.2 & 39.1 & 1.7 & 615 & 3.0 \\
\hline & 2017 & 34.8 & 33.0 & 2.8 & 415 & 3.7 \\
\hline \multirow[t]{2}{*}{17} & 2018 & 35.5 & 27.2 & 3.7 & 394 & 4.4 \\
\hline & 2019 & 31.6 & 40.2 & 1.8 & 434 & 2.9 \\
\hline
\end{tabular}

At the end of the maize growth cycle of $2018, \mathrm{~T}_{c}$ was measured once maize plants were senescent with a handheld infrared thermometer (model MI-230, Apogee Instruments 
Ltd., Logan, UT, USA) at 12:00 UTC in the period of 3-7 September. Under these conditions wherein the crop does not transpire, the measured $\Delta \mathrm{T}$ values can be considered as $\Delta \mathrm{T}_{d r y}$.

\subsection{Plant Level Measurements}

Canopy temperature $\left(\mathrm{T}_{c}\right)$ was measured in each of the 36 selected maize breeding plots with a portable infrared thermometer (model MI-230, Apogee Instruments Ltd., Logan, UT, USA) with a hand-held display, $14^{\circ}$ half-angle field of view and a response time of $0.6 \mathrm{~s}$. Three nadir-view canopy temperature measurements were taken and averaged per plot. Measurements were performed around noon on eight $(2017,2018)$ and four $(2019)$ measurement dates.

Leaf gas exchange was measured in one leaf per plot and in the same plots where $\mathrm{T}_{c}$ was measured with the portable CIRAS- 3 infrared gas analyzer (PP systems, Hitchin, Hertfordshire, UK). Measurements were performed between 11:00 and 12:30 h UTC on four (2017), five (2018), and three (2019) sampling dates. Leaf photosynthesis $\left(\mathrm{A}, \mu \mathrm{mol} \mathrm{m}{ }^{-2} \mathrm{~s}^{-1}\right)$ and stomatal conductance to water vapor $\left(\mathrm{g}_{\mathrm{s}}, \mathrm{mmol} \mathrm{m}^{-2} \mathrm{~s}^{-1}\right)$ were measured. The photosynthetic photon flux density (PPFD), provided by an internal LED light source, was set at $1500 \mu \mathrm{mol} \mathrm{m}{ }^{-2} \mathrm{~s}^{-1}$. The ambient $\mathrm{CO}_{2}$ concentration in the chamber was set at $400 \mu \mathrm{mol} \mathrm{mol}^{-1}$ by the CIRAS-3 injection system, which controlled and adjusted the flow of $\mathrm{CO}_{2}$ from a $\mathrm{CO}_{2}$ cylinder.

\subsection{Determination of Crop Water Stress Index (CWSI)}

The CWSI was computed using Equation (1):

$$
\text { CWSI }=\frac{\Delta \mathrm{T}-\Delta \mathrm{T}_{p o t}}{\Delta \mathrm{T}_{d r y}-\Delta \mathrm{T}_{p o t}}
$$

where $\Delta \mathrm{T}$ is the difference between canopy temperature $\left(\mathrm{T}_{c},{ }^{\circ} \mathrm{C}\right)$ and air temperature $\left(\mathrm{T}_{a}\right.$, ${ }^{\circ} \mathrm{C}$ ) for the prevailing conditions; $\Delta \mathrm{T}_{d r y}$ is the difference between $\mathrm{T}_{c}$ and $\mathrm{T}_{a}$ for a nontranspiring crop, and $\Delta \mathrm{T}_{p o t}$ is the difference between $\mathrm{T}_{\mathcal{c}}$ and $\mathrm{T}_{a}$ for a crop transpiring at its potential rate $[11,18]$.

The references $\Delta \mathrm{T}_{p o t}$ and $\Delta \mathrm{T}_{d r y}$ were determined using the reference baselines introduced by Idso et al. [18]:

$$
\begin{gathered}
\Delta \mathrm{T}_{\text {pot }}=\mathrm{a}_{\text {pot }}+\mathrm{b}_{\text {pot }} \cdot \mathrm{VPD} \\
\Delta \mathrm{T}_{d r y}=\mathrm{a}_{\text {pot }}+\mathrm{b}_{\text {pot }} \cdot\left[e^{*}\left(\mathrm{~T}_{a}\right)-e^{*}\left(\mathrm{~T}_{a}+\mathrm{a}_{\text {pot }}\right)\right]
\end{gathered}
$$

where $\mathrm{a}_{\text {pot }}$ and $\mathrm{b}_{\text {pot }}$ are two crop-specific constants; VPD is the vapor pressure deficit of the atmosphere, and $e^{*}\left(\mathrm{~T}_{a}\right)$ and $e^{*}\left(\mathrm{~T}_{a}+\mathrm{a}_{p o t}\right)$ are the saturated vapor pressures at temperatures $\mathrm{T}_{a}$ and $\mathrm{T}_{a}+\mathrm{a}_{\text {pot }}$, respectively. Equation (2) is often referred to as the non-water-stressed baseline (NWSB), whereas Equation (3) is usually referred to as the water-stressed baseline (WSB). Table 4 shows the values of the parameters $\mathrm{a}_{\text {pot }}$ and $\mathrm{b}_{\text {pot }}$ that have been obtained in previous scientific works for maize. Although there are some works that do not report the hourly period used for the estimation of these values, the rest of the works report that the values were obtained using crop temperature data corresponding to a period of several hours around noon. The studies are also classified according to the climatic region where the $a_{\text {pot }}$ and $b_{\text {pot }}$ values were obtained, there being only two studies carried out in the Mediterranean area whose climatic conditions may thus be similar to those existing in this study. 
Table 4. Summary of the reference baselines previously determined for computing empirical CWSI in maize. Unk $=$ unknown, $\mathrm{A} / \mathrm{SA}=$ arid $/$ semiarid, $\mathrm{HC}=$ humid continental, $\mathrm{MC}=$ monsoon continental, $\mathrm{MD}=\mathrm{Mediterranean}, \mathrm{SH}-$ $\mathrm{ST}$ = subhumid-subtropical, $\mathrm{H}-\mathrm{ST}=$ humid-subtropical, VEG = vegetative, $\mathrm{FLO}=$ flowering, $\mathrm{GF}=$ grain-filling, $\mathrm{CB}=\mathrm{common}$ baseline, $\mathrm{REP}=$ reproductive; $\mathrm{MAT}=$ maturation, $\mathrm{SEED}=$ seedling, $\mathrm{NA}=$ not available.

\begin{tabular}{|c|c|c|c|c|c|c|c|c|}
\hline Source & Location & Year & Time (h) & Climate & Stage & $\begin{array}{l}\mathrm{a}_{\text {pot }} \\
\left({ }^{\circ} \mathbf{C}\right)\end{array}$ & $\begin{array}{c}\mathbf{b}_{\text {pot }} \\
\left({ }^{\circ} \mathbf{C ~ k P a}^{-1}\right)\end{array}$ & $\begin{array}{c}\Delta \mathrm{T}_{d r y}{ }^{3} \\
\left({ }^{\circ} \mathrm{C}\right)\end{array}$ \\
\hline \multirow[t]{3}{*}{ [16] } & \multirow[t]{3}{*}{ Urmia (Iran) } & \multirow[t]{3}{*}{2017} & \multirow[t]{3}{*}{$9-15$} & \multirow[t]{3}{*}{ A/SA } & VEG & 3.28 & -1.78 & 4.69 \\
\hline & & & & & FLO & 2.22 & -1.24 & 2.83 \\
\hline & & & & & GF & 6.80 & -1.85 & 10.01 \\
\hline [12] & Arizona (USA) & Unk & Unk & $\mathrm{A} / \mathrm{SA}$ & VEG & 3.11 & -1.97 & Unk \\
\hline [24] & Colorado (USA) & 2011 & $10-14$ & $\mathrm{~A} / \mathrm{SA}$ & $\mathrm{CB}$ & 2.73 & -1.90 & 4.15 \\
\hline [23] & Colorado (USA) & 2011 & $10-14$ & $\mathrm{~A} / \mathrm{SA}$ & $\mathrm{CB}$ & 3.04 & -1.99 & 4.38 \\
\hline [36] & Isfahan (Iran) & 2013 & Unk & $\mathrm{A} / \mathrm{SA}$ & $\mathrm{CB}$ & -1.71 & -1.41 & $2.30^{4}$ \\
\hline [15] & Colorado (USA) & 2015 & $11-14$ & $\mathrm{~A} / \mathrm{SA}$ & $\mathrm{CB}$ & 3.43 & -1.97 & Unk \\
\hline [6] & Colorado (USA) & $2012 / 13$ & Unk & $\mathrm{A} / \mathrm{SA}$ & $\mathrm{CB}$ & 2.34 & -1.79 & $5.00^{4}$ \\
\hline [29] & $\begin{array}{c}\text { North Dakota } \\
\text { (USA) }\end{array}$ & 1989 & Unk & $\mathrm{HC}$ & CB & 2.14 & -1.97 & $5.00^{4}$ \\
\hline \multirow[t]{2}{*}{ [25] } & Inner Mongolia & \multirow[t]{2}{*}{2017} & \multirow[t]{2}{*}{ 11-13 } & \multirow[t]{2}{*}{$\mathrm{MC}$} & REP & 0.42 & -2.64 & 0.70 \\
\hline & (China) & & & & MAT & 2.96 & -3.35 & 0.80 \\
\hline [27] & Nebraska (USA) & 2004 & Unk & $\mathrm{HC}$ & $\mathrm{CB}$ & $1.58^{1}$ & $-1.66^{1}$ & $1.61^{1}$ \\
\hline [30] & Nebraska (USA) & Unk & Unk & $\mathrm{HC}$ & $\mathrm{CB}$ & 2.67 & -2.06 & $3.00^{4}$ \\
\hline [28] & Antalya (Turkey) & 1995 & Unk & MD & $\mathrm{CB}$ & 1.39 & -0.86 & $4.60^{4}$ \\
\hline \multirow[t]{2}{*}{ [34] } & \multirow[t]{2}{*}{ Adana (Turkey) } & 1993 & \multirow[t]{2}{*}{$12-14$} & \multirow[t]{2}{*}{ MD } & $\mathrm{CB}$ & 2.90 & -2.66 & 4.25 \\
\hline & & 1994 & & & $\mathrm{CB}$ & 2.41 & -2.05 & 3.50 \\
\hline [26] & Salto (Argentina) & $1995 / 96$ & $11-14$ & H-ST & $\mathrm{CB}$ & 2.95 & -1.78 & $\approx 4-5$ \\
\hline [31] & Orissa (India) & $2004 / 05$ & $11-14$ & SH-ST & $\mathrm{CB}$ & -3.77 & -1.10 & $-1.00^{4}$ \\
\hline [9] & Morelos (México) & $2010 / 11$ & $11-14$ & ST & $\begin{array}{l}\text { REP- } \\
\text { MAT }\end{array}$ & $\mathrm{NA}^{2}$ & $\mathrm{NA}^{2}$ & $5.00^{4}$ \\
\hline \multirow[t]{3}{*}{ [32] } & \multirow[t]{3}{*}{ Jiangsu (China) } & \multirow[t]{3}{*}{ 2013/14/15 } & \multirow[t]{3}{*}{$10-15$} & \multirow[t]{3}{*}{ ST } & VEG & 3.55 & -1.00 & Unk \\
\hline & & & & & REP & 5.08 & -3.30 & Unk \\
\hline & & & & & MAT & 8.53 & -5.30 & Unk \\
\hline \multirow[t]{4}{*}[33]{$^{5}$} & \multirow[t]{4}{*}{ Kansas (USA) } & \multirow[t]{4}{*}{2014} & \multirow[t]{4}{*}{$12-17$} & \multirow[t]{4}{*}{$\mathrm{H}-\mathrm{ST}$} & SEED & 2.95 & -3.39 & $5.00^{4}$ \\
\hline & & & & & VEG & 3.52 & -3.40 & $5.00^{4}$ \\
\hline & & & & & REP & 4.21 & -2.78 & $5.00^{4}$ \\
\hline & & & & & MAT & 4.23 & -2.74 & $5.00^{4}$ \\
\hline
\end{tabular}

${ }^{1}$ The NWSB and WSB determined by these authors included VPD, solar radiation $\left(\mathrm{R}_{s}\right)$, wind speed $(\mathrm{u})$, and crop height $(\mathrm{h})$ as independent variables. These values were derived for $\mathrm{R}_{s}=800 \mathrm{~W} \mathrm{~m}^{-2}, \mathrm{u}=2 \mathrm{~m} \mathrm{~s}^{-1}$, and $\mathrm{h}=2.7 \mathrm{~m}$. ${ }^{2}$ These authors used wet bulb temperature measured with a psychrometer as a surrogate of $\mathrm{T}_{\text {pot }}{ }^{3}$ Mean $\Delta \mathrm{T}_{d r y}$ values provided by the authors for the mean air temperature prevailing during the experimental period. ${ }^{4} \mathrm{~A}$ fixed $\Delta \mathrm{T}_{d r y}$ value was used for computing CWSI. ${ }^{5}$ Experiment conducted under greenhouse conditions.

In 2018, the CWSI was also determined on three sampling dates using the wet and dry artificial reference surfaces developed by Apolo-Apolo et al. [8] and Equation (4):

$$
\text { CWSI }=\frac{\mathrm{T}_{c}-\mathrm{T}_{p o t}}{\mathrm{~T}_{d r y}-\mathrm{T}_{\text {pot }}}
$$

where $\mathrm{T}_{p o t}$ and $\mathrm{T}_{d r y}$ are the crop temperature under non-limiting soil moisture conditions (transpiring at potential rate) and under maximum water-stress conditions (non-transpiring crop) measured with the wet and dry ARS, respectively. The ARSs were installed on a wooden structure that was attached to a mast at a height of $3 \mathrm{~m}$, coinciding with the height of the maize plants. The wet ARSs were kept wet as described in Apolo-Apolo et al. [8]. The ARS was equipped with inexpensive infrared thermal sensors (MLX90614 from Melexis, Ypres, Belgium) that take ARS temperature readings at 30 min intervals. See ApoloApolo et al. [8] for further details. 


\subsection{Statistical and Sensitivity Analyses}

The relationships between $\mathrm{T}_{c}-\mathrm{T}_{a}$ and VPD (NWSBs), as well as between CWSI and the physiological measurements, were analyzed through linear regression analyses, and the coefficient of determination $\left(R^{2}\right)$ was used to assess the goodness of fit of the regression lines. Significant differences between slopes and non-zero intercepts of the NWSBs obtained diurnally were evaluated with the Comparison of Regression Lines tool included in the statistical package Statgraphics (Statgraphics Centurion XV). An analysis of the sensitivity of CWSI to the fitted $\mathrm{a}_{\text {pot }} / \mathrm{b}_{\text {pot }}$ parameters and to VPD was also performed.

\section{Results}

\subsection{Non-Water-Stressed and Water-Stressed Reference Baselines for Maize under Mediterranean Climate}

Figure 2 shows the relationship between $\Delta \mathrm{T}_{\text {pot }}$ and VPD obtained when data for the time period 10-17 UTC and three growing seasons (2017, 2018, and 2019) are pooled together. The relationship is highly significant $(p<0.0001)$, has a coefficient of determination $\left(\mathrm{R}^{2}\right)$ of 0.84 , and covers a wide range of VPD values $(\approx 0.8$ to $7.5 \mathrm{kPa})$, with 2018 being the year in which the highest atmospheric demand values were observed. The intercept and slope of the derived NWSB were $4.16^{\circ} \mathrm{C}$ and $-1.49{ }^{\circ} \mathrm{C} \mathrm{kPa}^{-1}$, respectively.

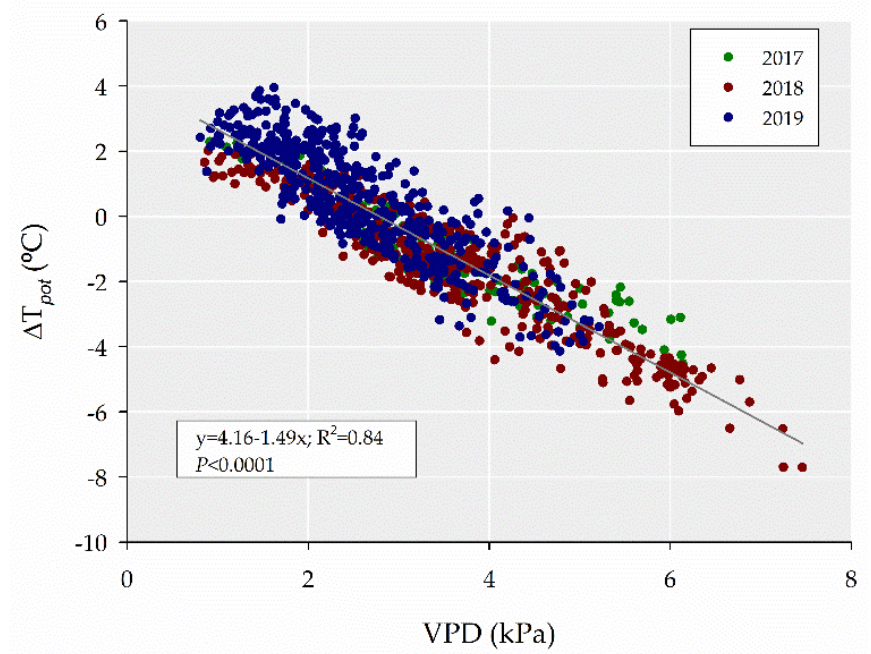

Figure 2. Relationship between canopy-to-air temperature difference of well-watered maize plants $\left(\Delta \mathrm{T}_{\text {pot }}\right)$ and vapor pressure deficit (VPD). Data from the time interval 10-17 UTC and from three growing seasons $(2017,2018,2019)$ are pooled together. Each point represents a single maize breeding plot. The straight line is the best-fit regression line.

Despite the close relationship found between $\Delta \mathrm{T}_{\text {pot }}$ and $\mathrm{VPD}$ for data gathered during the period 10-17 $\mathrm{h}$ (Figure 2), the goodness of fit improved notably when the dataset was split at the hourly level (Figure 3$)$. Table 5 shows the intercepts $\left(a_{p o t}\right)$, slopes $\left(b_{p o t}\right)$, and $R^{2}$ values of the NWSBs derived at the hourly level. The observed $R^{2}$ values vary between 0.85 (13:00 UTC) and 0.93 (17:00 UTC); the fitted a pot values vary between $2.83^{\circ} \mathrm{C}(17: 00 \mathrm{UTC})$ and $5.80{ }^{\circ} \mathrm{C}(13: 00 \mathrm{UTC})$ and the fitted $\mathrm{b}_{\text {pot }}$ values vary between $-1.34{ }^{\circ} \mathrm{C} \mathrm{kPa}^{-1}(16: 00$ and 17:00 UTC) and $-1.85^{\circ} \mathrm{C} \mathrm{kPa}^{-1}$ (10:00 UTC). Significant differences $(p<0.05)$ were observed between the $\mathrm{a}_{\text {pot }}$ values obtained at different times of the interval 10:00-17:00 UTC, except the values derived at 12:00 and 14:00 UTC that were statistically similar. Significant differences in $b_{\text {pot }}$ were also observed during the period 10:00-17:00 UTC, although the values were relatively similar between 10:00-13:00 UTC and between 15:00-17:00 UTC. The $b_{\text {pot }}$ value observed at 14:00 UTC was significantly different from those observed in the abovementioned time intervals (Table 5). 

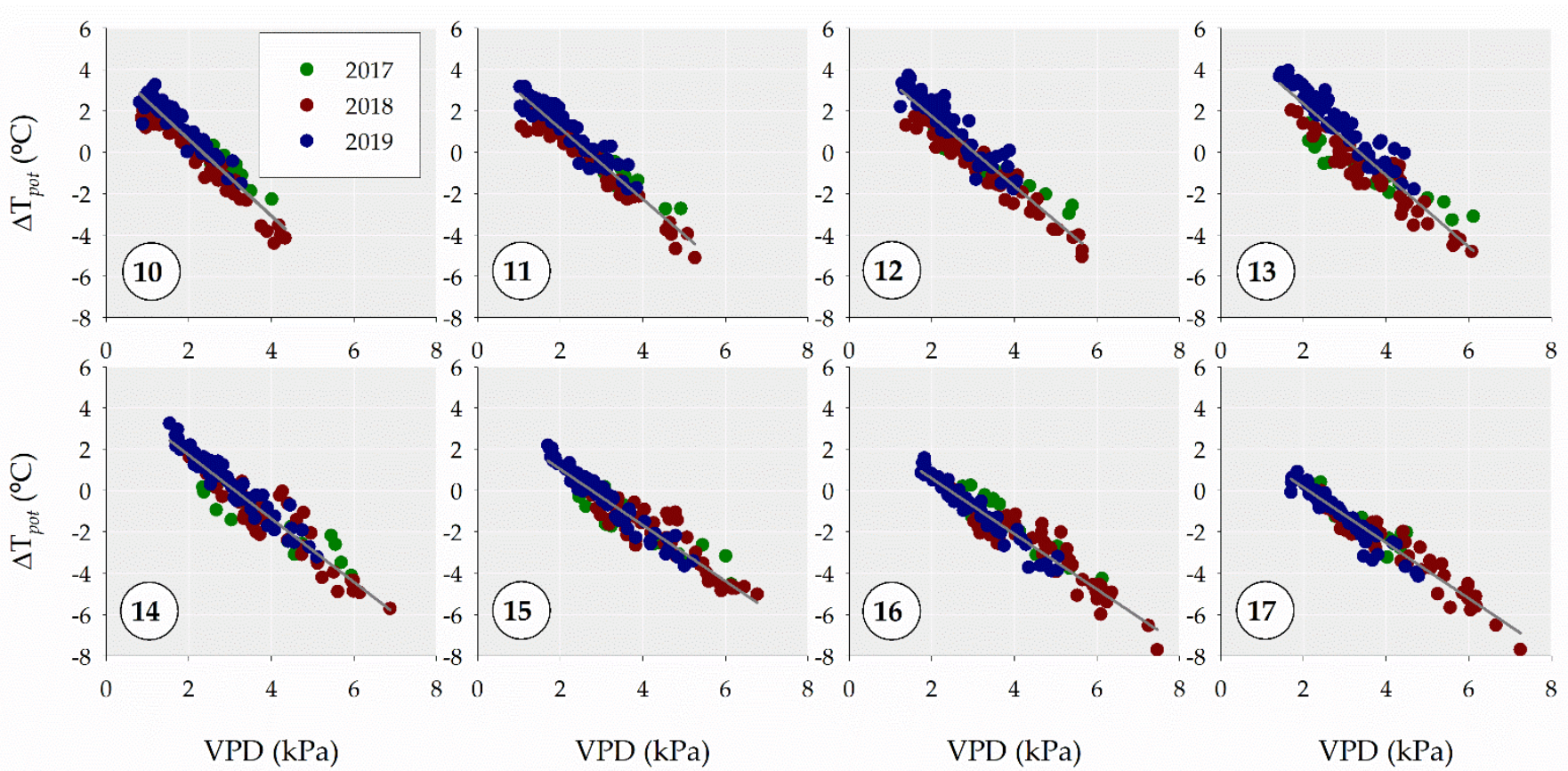

Figure 3. Relationship between hourly canopy-to-air temperature difference of well-watered maize plants $\left(\Delta \mathrm{T}_{\text {pot }}\right)$ and vapor pressure deficit (VPD). Each panel depicts data of a single hour within the time interval 10-17 UTC; the number inside the circle within each panel indicates the UTM hour of that plot. Data from three growing seasons $(2017,2018,2019)$ are pooled together. Each point represents a single maize breeding plot. The straight lines are the best-fit regression lines.

Table 5. The fitted parameters and coefficients of determination $\left(\mathrm{R}^{2}\right)$ for the hourly non-waterstressed baselines $\left(\Delta \mathrm{T}_{\text {pot }}=\mathrm{a}_{\text {pot }}+\mathrm{b}_{\text {pot }} \cdot \mathrm{VPD}\right)$ are shown in Figure 3. Only clear-sky (cloudless) days of the DOY periods 206 to 217 (2017), 207 to 231 (2018), and 172 to 211 (2019) were used in the analyses. Pooled data gathered during the 2017, 2018, and 2019 growth seasons were used. UTC: Universal Time Coordinated.

\begin{tabular}{cccc}
\hline UTC & $\mathbf{a}_{\text {pot }}\left({ }^{\circ} \mathbf{C}\right)$ & $\mathbf{b}_{\text {pot }}\left({ }^{\circ} \mathbf{C} \mathbf{~ k P a} \mathbf{P a}^{-\mathbf{1}}\right.$ & $\mathbf{R}^{\mathbf{2}}$ \\
\hline $10: 00$ & $4.33 \mathrm{~d}$ & $-1.85 \mathrm{a}$ & 0.90 \\
$11: 00$ & $4.59 \mathrm{c}$ & $-1.72 \mathrm{ab}$ & 0.91 \\
$12: 00$ & $5.13 \mathrm{~b}$ & $-1.69 \mathrm{~b}$ & 0.89 \\
$13: 00$ & $5.80 \mathrm{a}$ & $-1.73 \mathrm{ab}$ & 0.85 \\
$14: 00$ & $4.77 \mathrm{~b}$ & $-1.53 \mathrm{c}$ & 0.90 \\
$15: 00$ & $3.73 \mathrm{e}$ & $-1.35 \mathrm{~d}$ & 0.90 \\
$16: 00$ & $3.25 \mathrm{f}$ & $-1.34 \mathrm{~d}$ & 0.91 \\
$17: 00$ & $2.83 \mathrm{~g}$ & $-1.34 \mathrm{~d}$ & 0.93 \\
\hline
\end{tabular}

Different letters within the $\mathrm{a}_{\text {pot }}$ and $\mathrm{b}_{\text {pot }}$ columns indicate significant differences at $p<0.05$.

The diurnal evolution of $\mathrm{a}_{\text {pot }}$ and $\mathrm{b}_{\text {pot }}$ can be explained by the variation in the meteorological conditions observed during the 10:00-17:00 UTC time interval. In this regard, the derived $\mathrm{a}_{\text {pot }}$ and $\mathrm{b}_{\text {pot }}$ values showed a strong curvilinear relationship with solar radiation (Figure $4 a$ ) and the slope of the saturation vapor pressure curve (Figure $4 b$ ), respectively. An explanation for the diurnal shifting of $\mathrm{a}_{\text {pot }}$ and $\mathrm{b}_{\text {pot }}$ is provided by the theoretical equation of NWSB $[10,11]$, which denotes the mutual dependence of $\mathrm{a}_{\text {pot }}$ with net radiation and of $b_{\text {pot }}$ with the slope of the saturation vapor pressure curve.

Figure 5 shows a sensitivity analysis of the impact on CWSI of using a common NWSB equation or several equations obtained at certain time periods. As an example, for $\Delta \mathrm{T}$ of $2{ }^{\circ} \mathrm{C}$ and low VPD conditions ( $\left.<2 \mathrm{kPa}\right), \mathrm{CWSI}$ differences of 0.23 and 0.35 are observed at $13 \mathrm{~h}$ and $17 \mathrm{~h}$, respectively, when a common equation instead of the equation derived for those particular time periods is used. Although the differences in CWSI persist for high VPD conditions, they decrease as VPD increases. 


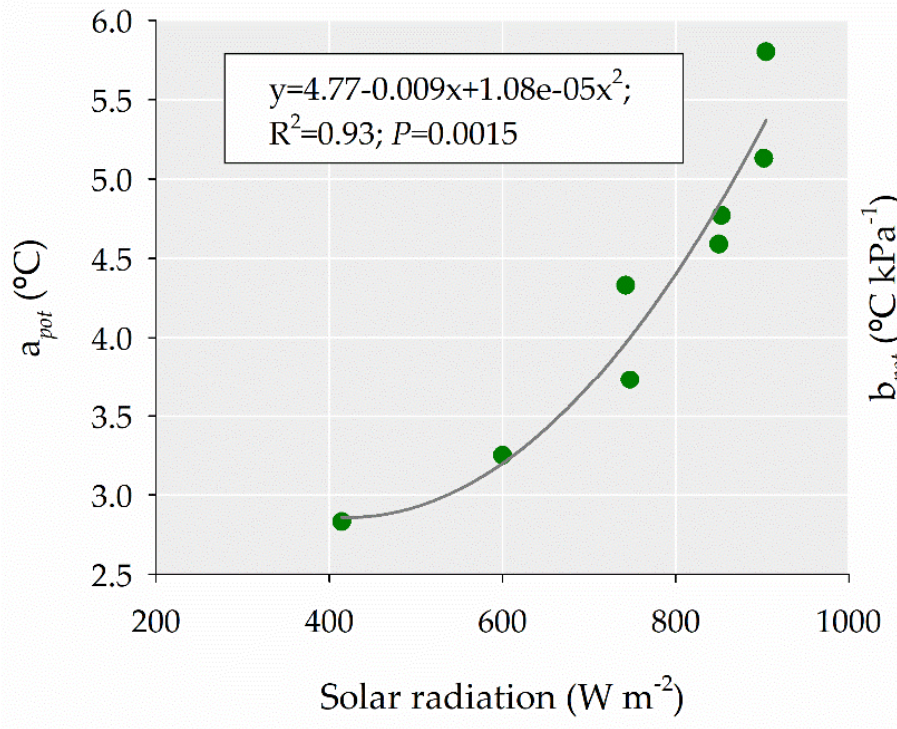

(a)

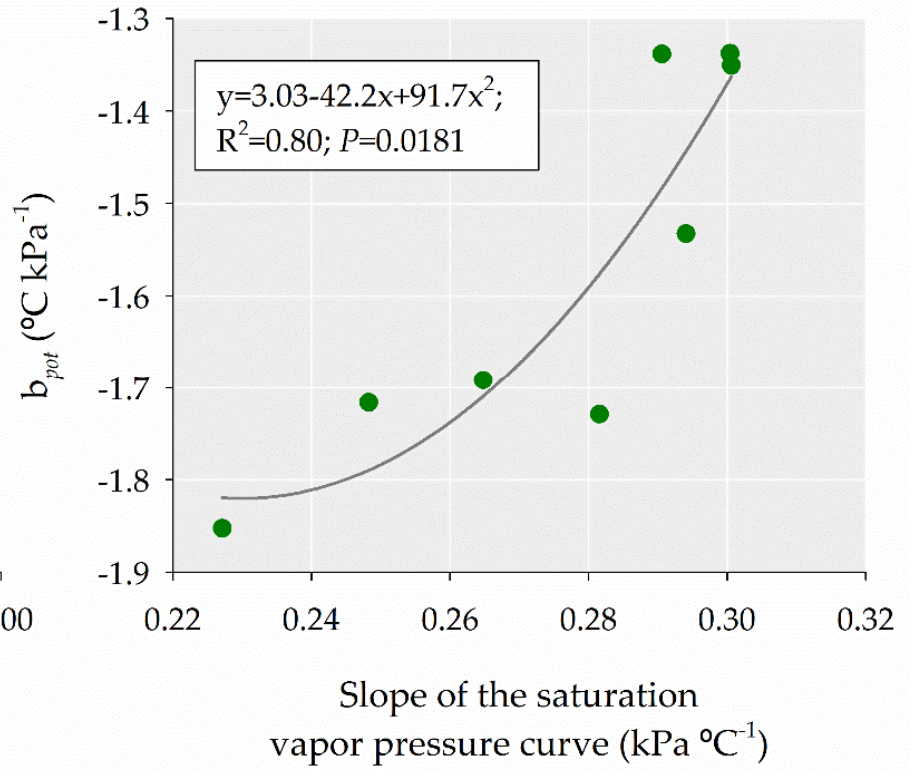

(b)

Figure 4. (a) Relationship between hourly $\mathrm{a}_{\text {pot }}$ values and solar radiation; (b) relationship between $\mathrm{b}_{\text {pot }}$ and the slope of the saturation vapor pressure curve. The curvilinear lines in $(\mathbf{a}, \mathbf{b})$ represent the best-fit regression lines.

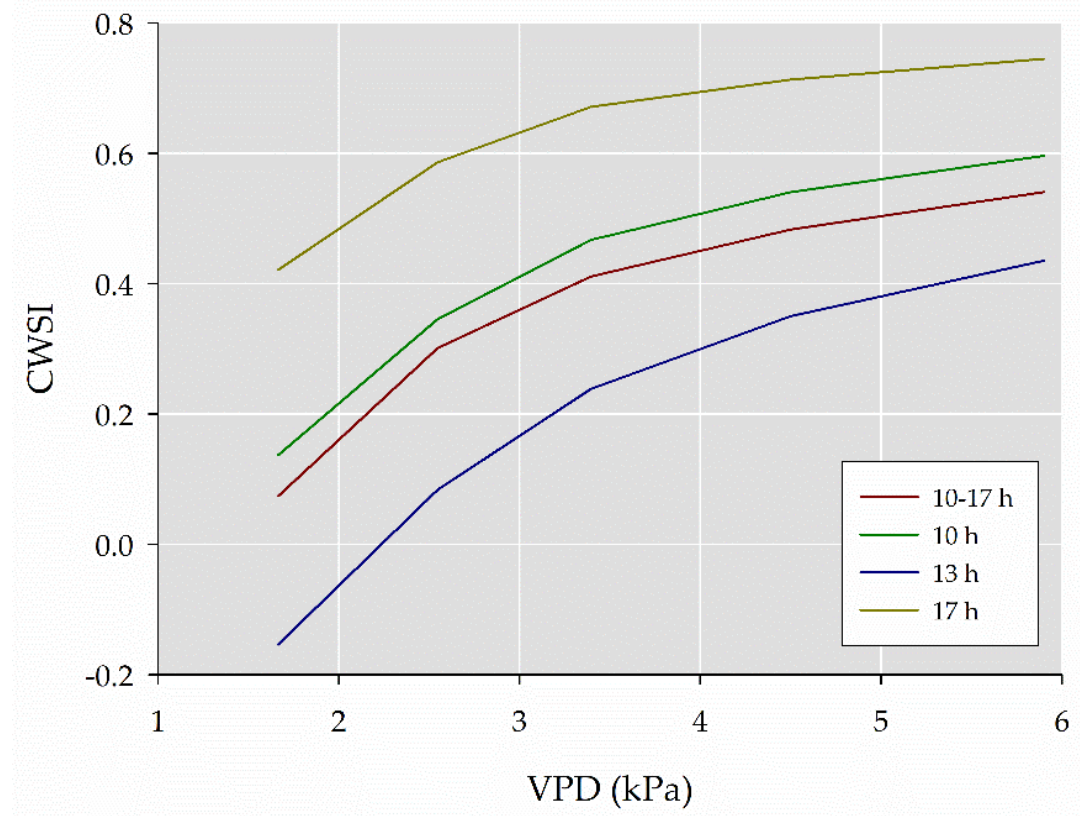

Figure 5. Sensitivity analysis of crop water stress index (CWSI) to four pairs of $a_{p o t} / b_{\text {pot }}$ values: (1) values derived for the period 10-17 h UTC, (2) values derived for the $10 \mathrm{~h}$ UTC time period, (3) values derived for the $13 \mathrm{~h}$ UTC time period, (4) values derived for the $17 \mathrm{~h}$ UTC time period. Equations (1)-(3) have been used to compute CWSI. A fixed $\Delta \mathrm{T}$ value of $2{ }^{\circ} \mathrm{C}$ was used in all cases.

With respect to WSB, Figure 6 shows the evolution of the mean $\Delta \mathrm{T}_{\text {dry }}$ values calculated during the time interval 10:00-17:00 UTC using the hourly mean air temperature values recorded during the experimental period. The mean $\Delta \mathrm{T}_{d r y}$ values showed a bell-shaped pattern, with increasing values from 10:00 (UTC) $\left(6.4^{\circ} \mathrm{C}\right)$ to $13: 00$ (UTC) $\left(8.1^{\circ} \mathrm{C}\right)$ and decreasing thereafter to $4.7^{\circ} \mathrm{C}$ (17 UTC). Solar radiation showed a similar pattern to $\Delta \mathrm{T}_{d r y}$ (Figure 6), suggesting that both variables are also strongly related. At the end of the 2018 growing season, $\Delta \mathrm{T}_{d r y}$ values were also measured in senescent maize plants at midday. 
As shown in Figure 6 , the measured $\Delta \mathrm{T}_{d r y}$ values were slightly higher $\left(7.8^{\circ} \mathrm{C}\right)$ than those estimated with Equation $(3)\left(7.3^{\circ} \mathrm{C}\right)$.

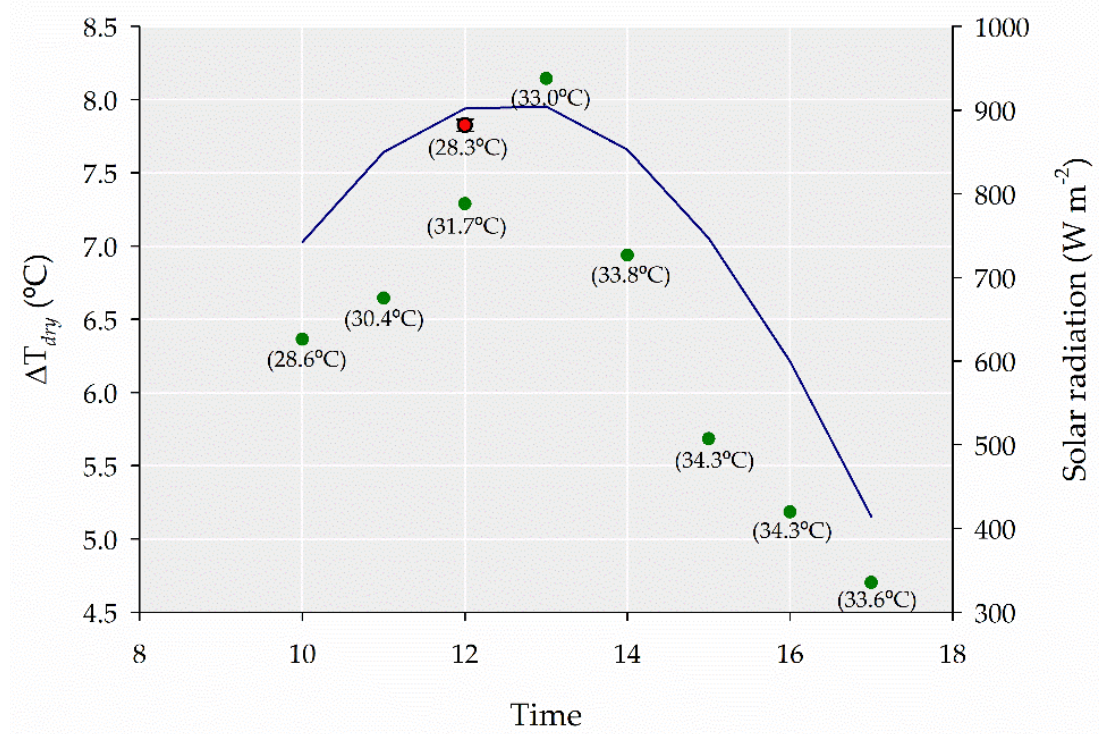

Figure 6. Daytime evolution of mean solar radiation (blue straight line) and mean $\Delta \mathrm{T}_{d r y}$ values (green symbols), derived with Equation (3) using hourly mean $\mathrm{T}_{a}$ values (numbers in brackets below each symbol) measured during the experimental periods of 2017-2019. Mean $\Delta \mathrm{T}_{d r y}$ values measured at midday in senescent (non-transpiring) maize plants during the 3rd-7th of September 2018 are also plotted (red symbol).

\subsection{Assessment of Crop Water Stress Index against Leaf Gas Exchange Measurements in Maize Breeding Plots}

The crop water stress index (CWSI) was determined for each experimental plot during the experimental periods of 2017, 2018 and 2019 using the NWSBs shown in Table 5 and the WSB described in Equation (3). The mean CWSI values per irrigation treatment are shown in Figure 7. In 2017, the WW and WS treatments showed mean CWSI values within the ranges -0.28 to 0.19 and 0.01 to 1.04 , respectively. In 2018, the WW and WS treatments presented mean CWSI values within the range -0.09 to 0.10 and 0.12 to 0.53 , respectively. In 2019, the corresponding mean CWSI ranges for WW, WS1, and WS2 were 0.04 to 0.11 , 0.16 to 0.82 , and -0.02 to 0.93 , respectively.

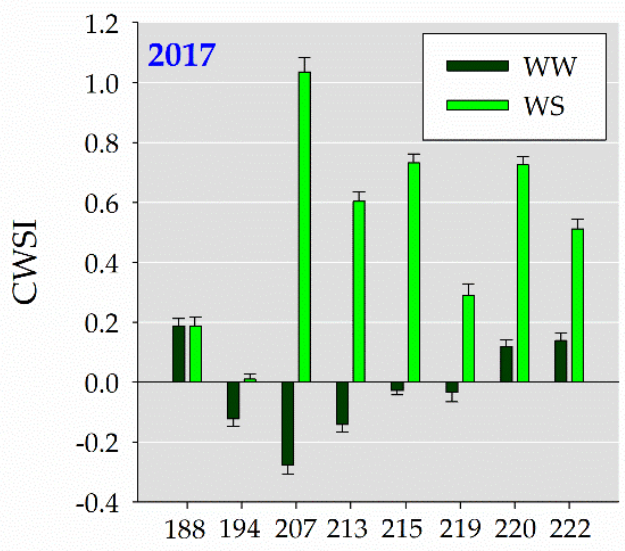

Day of year
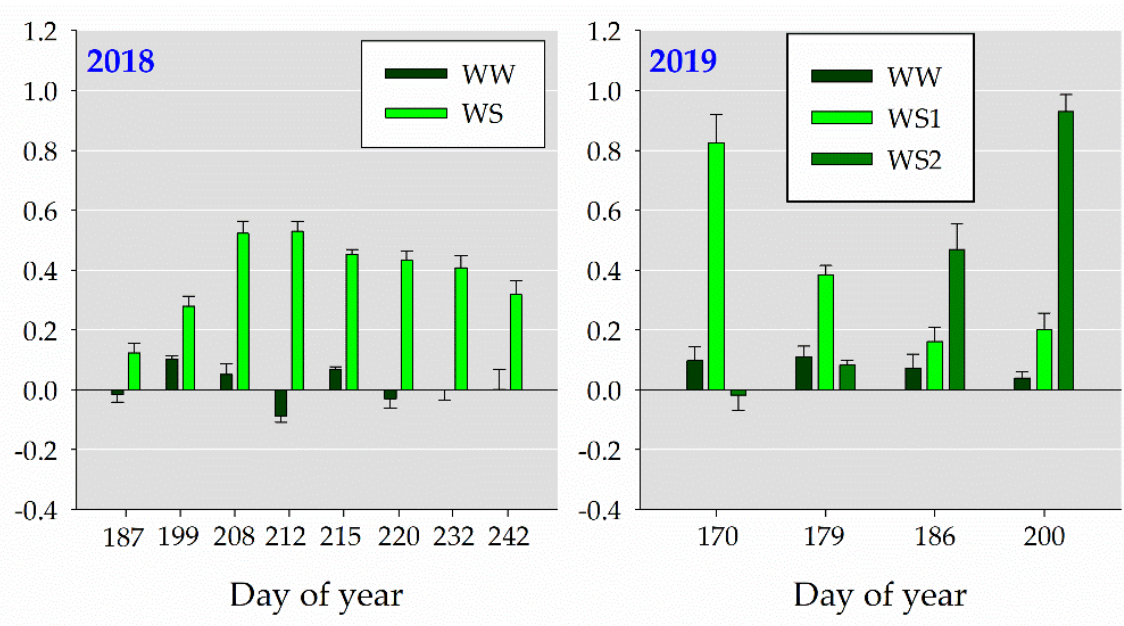

Figure 7. Mean crop water stress index (CWSI) determined throughout the experimental periods of 2017, 2018, and 2019 in well-watered (WW) and water-stressed (WS) maize plots. In 2019, WS1 and WS2 stand for flowering and grain-filling water stress, respectively. Each bar indicates the mean \pm s.e. of $18(2017,2018)$ and $12(2019)$ maize breeding plots. 
The crop-to-air temperature difference $(\Delta \mathrm{T})$ has also been proposed on some occasions as a crop water status indicator. Figure 8 shows the $\Delta \mathrm{T}$ values observed during the periods of water deficit in the deficit irrigation treatments as well as the $\Delta \mathrm{T}_{d r y}$ values for each sampling date. The variable $\Delta \mathrm{T}_{d r y}$ represents the maximum $\Delta \mathrm{T}$ value that could theoretically be reached in the deficit treatments. On average, in 2017, the $\Delta \mathrm{T}$ values observed in the WS treatment were around $50 \%$ of $\Delta \mathrm{T}_{d r y}$. In 2018, WS presented $\Delta \mathrm{T}$ values that were around $32 \%$ of $\Delta \mathrm{T}_{d r y}$, while in $2019, \Delta \mathrm{T}$ values were around $52 \%$ and $61 \%$ of $\Delta \mathrm{T}_{d r y}$ in WS1 and WS2, respectively.
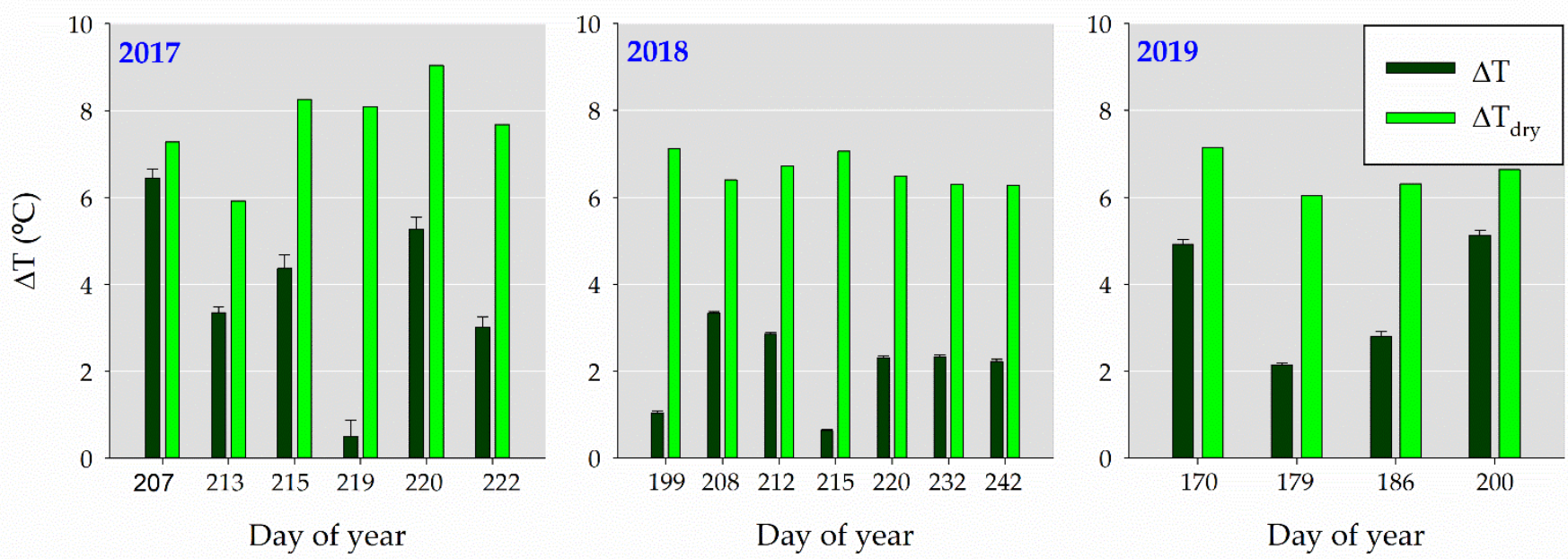

Figure 8. Mean $\Delta \mathrm{T}$ values observed during the water stress period in the deficit irrigation treatments (WS). In 2019, the first two dates correspond to the flowering stress treatment (WS1) and the last two dates to the grain-filling stress treatment (WS2). For each measurement date, the $\Delta \mathrm{T}_{d r y}$ values calculated with Equation (3) are also plotted. Each bar indicates the mean \pm s.e. of $18(2017,2018)$ and $12(2019)$ maize breeding plots.

Stomatal conductance $\left(\mathrm{g}_{\mathrm{s}}\right)$ and leaf photosynthesis rate $(\mathrm{A})$ averaged per irrigation treatment and date of measurement are shown in Figure 9. In 2017, the WW and WS treatments showed mean $\mathrm{g}_{\mathrm{s}}$ values within the ranges 150 to $350 \mathrm{mmol} \mathrm{m}^{-2} \mathrm{~s}^{-1}$ and 4 to $39 \mathrm{mmol} \mathrm{m}^{-2} \mathrm{~s}^{-1}$, respectively. In 2018, the WW and WS treatments presented mean $\mathrm{g}_{\mathrm{s}}$ values within the ranges 200 to $370 \mathrm{mmol} \mathrm{m}^{-2} \mathrm{~s}^{-1}$ and 50 to $210 \mathrm{mmol} \mathrm{m} \mathrm{m}^{-2} \mathrm{~s}^{-1}$, respectively. In 2019, the corresponding mean $\mathrm{g}_{\mathrm{s}}$ ranges for WW, WS1, and WS2 were 382 to $396 \mathrm{mmol} \mathrm{m}^{-2} \mathrm{~s}^{-1}, 92$ to $439 \mathrm{mmol} \mathrm{m}^{-2} \mathrm{~s}^{-1}$, and 8 to $326 \mathrm{mmol} \mathrm{m}^{-2} \mathrm{~s}^{-1}$, respectively. Regarding A, the WW and WS treatments showed mean A values in 2017 within the ranges 28 to $46 \mu \mathrm{mol} \mathrm{m}^{-2} \mathrm{~s}^{-1}$ and 0.3 to $8.8 \mu \mathrm{mol} \mathrm{m}^{-2} \mathrm{~s}^{-1}$, respectively. In 2018 , the corresponding mean A values for WW and WS treatments varied within the ranges 11 to $30 \mu \mathrm{mol} \mathrm{m} \mathrm{m}^{-2} \mathrm{~s}^{-1}$ and 11 to $23 \mu \mathrm{mol} \mathrm{m}{ }^{-2} \mathrm{~s}^{-1}$, respectively. In 2019, the WW, WS1, and WS2 treatments showed mean A values within the ranges 33 to $55 \mu \mathrm{mol} \mathrm{m}{ }^{-2} \mathrm{~s}^{-1}, 19$ to $61 \mu \mathrm{mol} \mathrm{m}{ }^{-2} \mathrm{~s}^{-1}$, and 4 to $44 \mu \mathrm{mol} \mathrm{m}^{-2} \mathrm{~s}^{-1}$, respectively.

The days when both CWSI and leaf gas exchange were measured (4 in 2017, 4 in 2018, and 3 in 2019) were used to analyze the suitability of the CWSI values derived using the NWSBs obtained in this study to monitor maize water stress. Significant linear relationships $(p<0.0001)$ were observed between $\mathrm{g}_{\mathrm{s}}$ and A with CWSI (Figure 10). The $\mathrm{g}_{\mathrm{s}}$ vs. CWSI linear relationship showed higher data scattering $\left(R^{2}=0.41\right)$ than the A vs. CWSI linear relationship ( $\left.R^{2}=0.63\right)$, particularly for CWSI values near zero (well-watered conditions). 

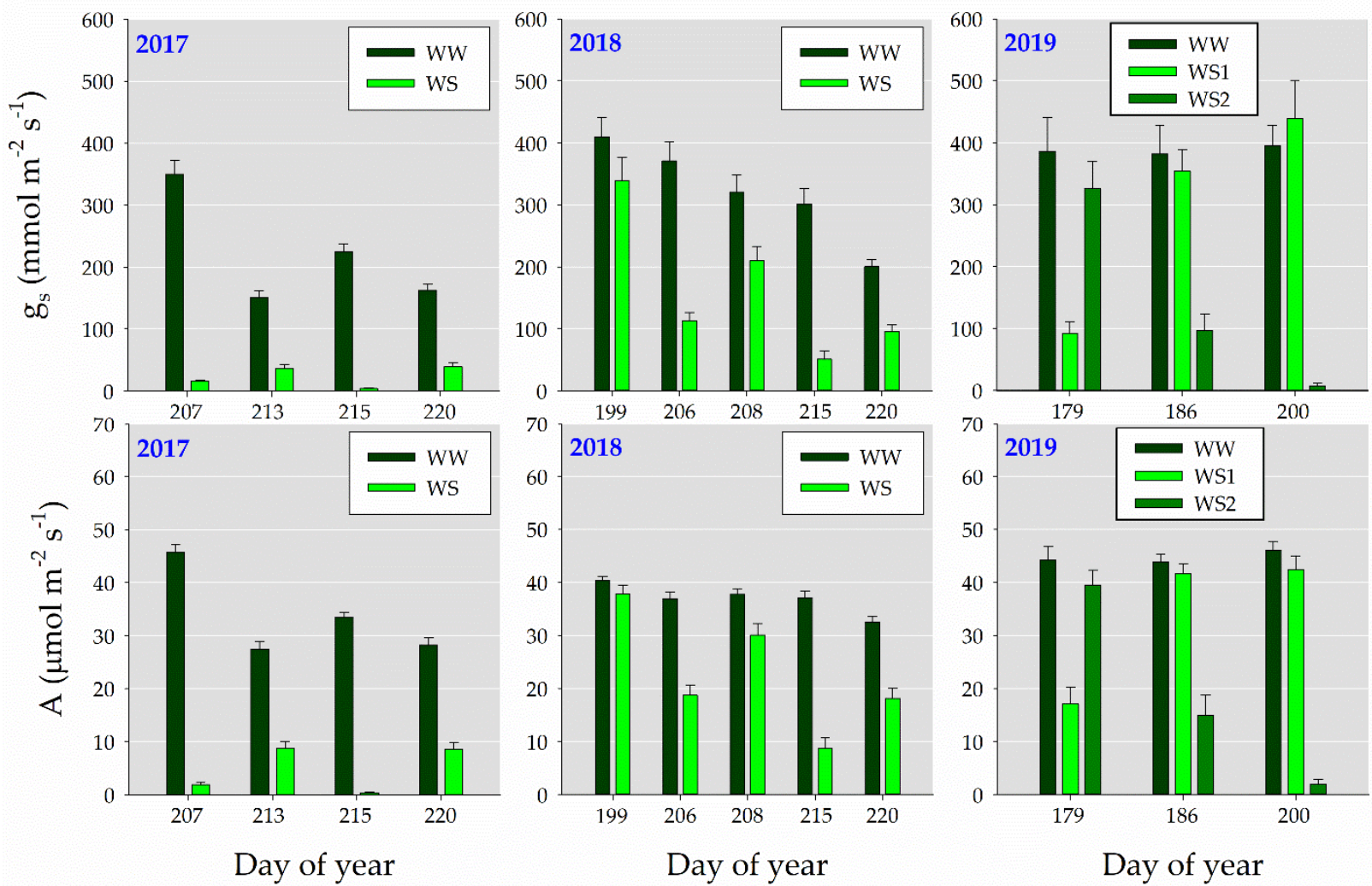

Figure 9. Mean stomatal conductance $\left(\mathrm{g}_{\mathrm{s}}\right)$ and leaf photosynthesis rate $(\mathrm{A})$ values determined throughout the experimental periods of 2017, 2018, and 2019 in well-watered (WW) and water-stressed (WS) maize plots. In 2019, WS1 and WS2 stand for flowering and grain-filling water stress, respectively. Each bar indicates the mean \pm s.e. of $18(2017,2018)$ and 12 (2019) maize breeding plots.
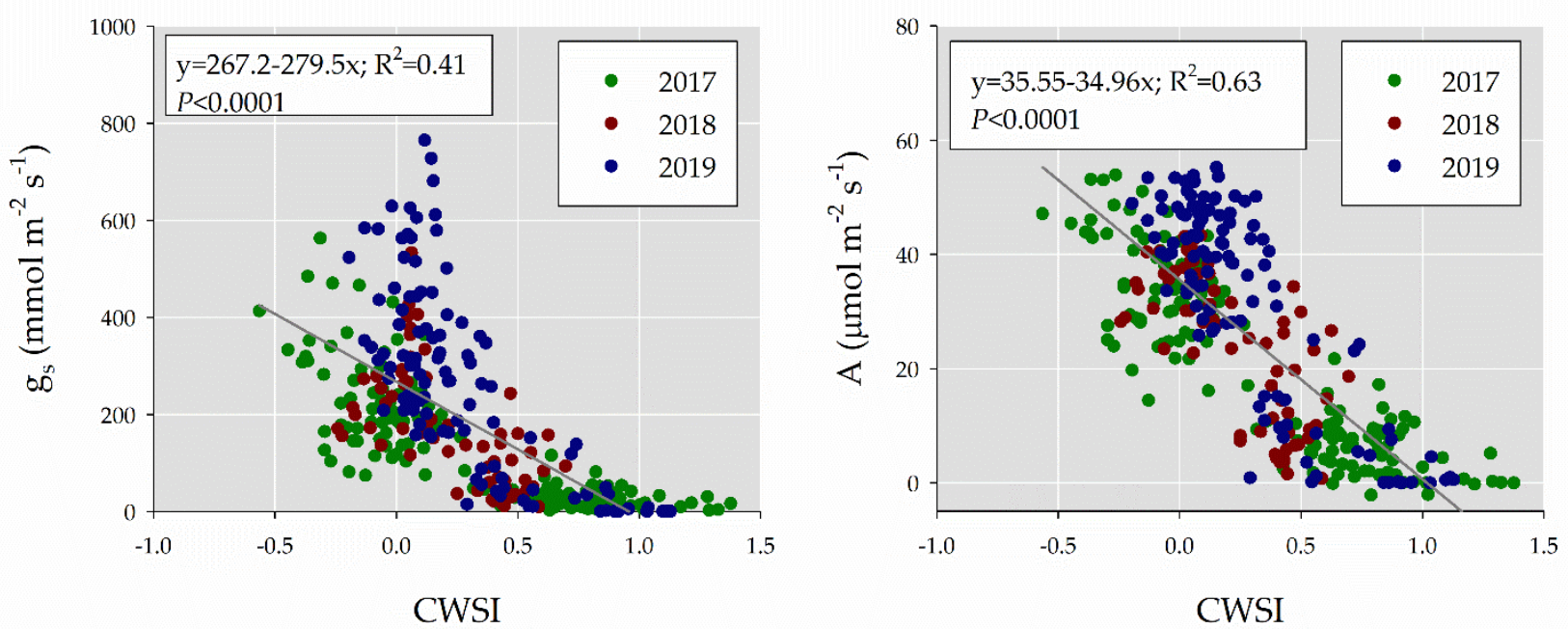

Figure 10. Relationship between crop water stress index (CWSI) and stomatal conductance $\left(\mathrm{g}_{\mathrm{s}}\right)$ and leaf photosynthesis rate (A). Each point represents a single maize breeding plot. The straight grey lines depict the best-fit regression lines.

\subsection{Comparison of NWSB-Based vs. ARS-Based Crop Water Stress Index}

On three sampling dates in 2018, the CWSI was determined in 18 WW and 18 WS maize breeding plots using both the NWSBs obtained in this study (Table 5) and the artificial reference surfaces (ARS) developed by Apolo-Apolo et al. [8] (Figure 11). The mean ARS-based CWSI values ranged within the interval 0.01 to 0.08 and 0.40 to 0.62 in WW and WS, respectively. The corresponding mean NWSB-based CWSI values ranged 
within the interval -0.09 to 0.07 and 0.43 to 0.53 in WW and WS, respectively. A close linear relationship $\left(\mathrm{R}^{2}=0.92\right)$ was observed between the mean CWSI values obtained with both methodologies.

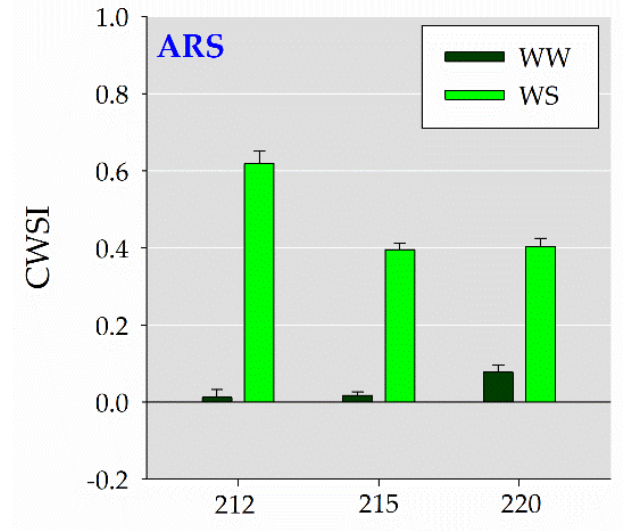

Day of year

(a)

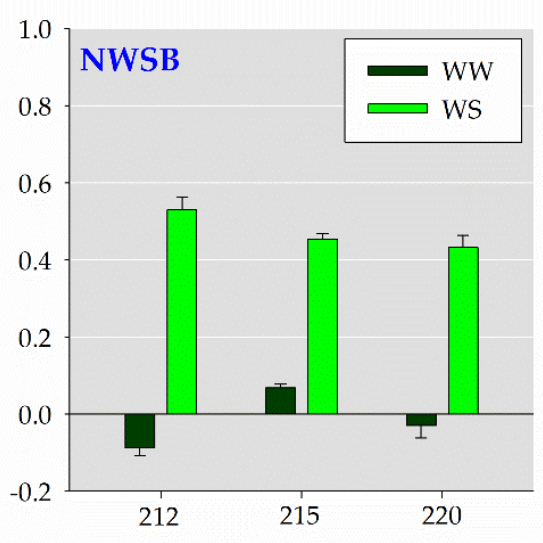

Day of year

(b)

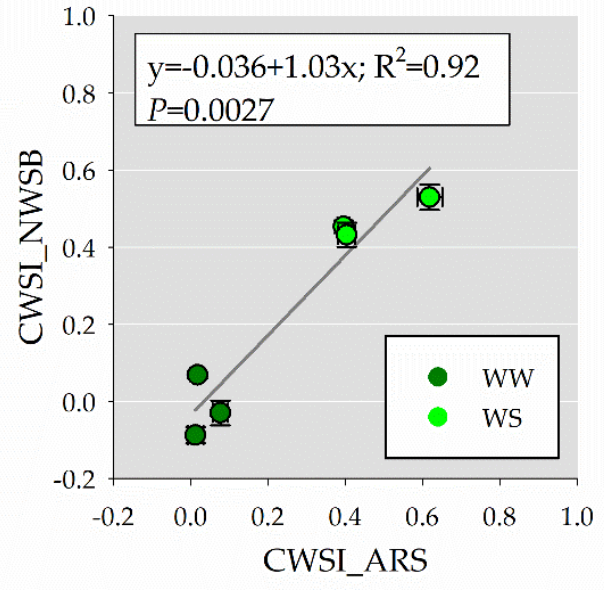

(c)

Figure 11. (a) ARS-based crop water stress index (CWSI) for WW and WS treatments, (b) NWSB-based CWSI for WW and WS treatments, and (c) the relationship between ARS-based and NWSB-based CWSI. The data comes from the 2018 growth cycle. In $(\mathbf{a}-\mathbf{c})$, the error bars represent the standard error of the mean $(n=18)$.

The relationship between the CWSI and $g_{s}$ and A was significant $(p<0.0001)$, regardless of the methodology used for CWSI determination (Figure 12). However, the ARS-based CWSI outperformed the NWSB-based CWSI, as the former explained a higher percentage of the observed variability in $\mathrm{g}_{\mathrm{s}}\left(\mathrm{R}^{2}\right.$ of 0.54 and 0.41 in ARS-based and NWSBbased CWSI, respectively) and A ( $\mathrm{R}^{2}$ of 0.58 and 0.52 in ARS-based and NWSB-based CWSI, respectively).
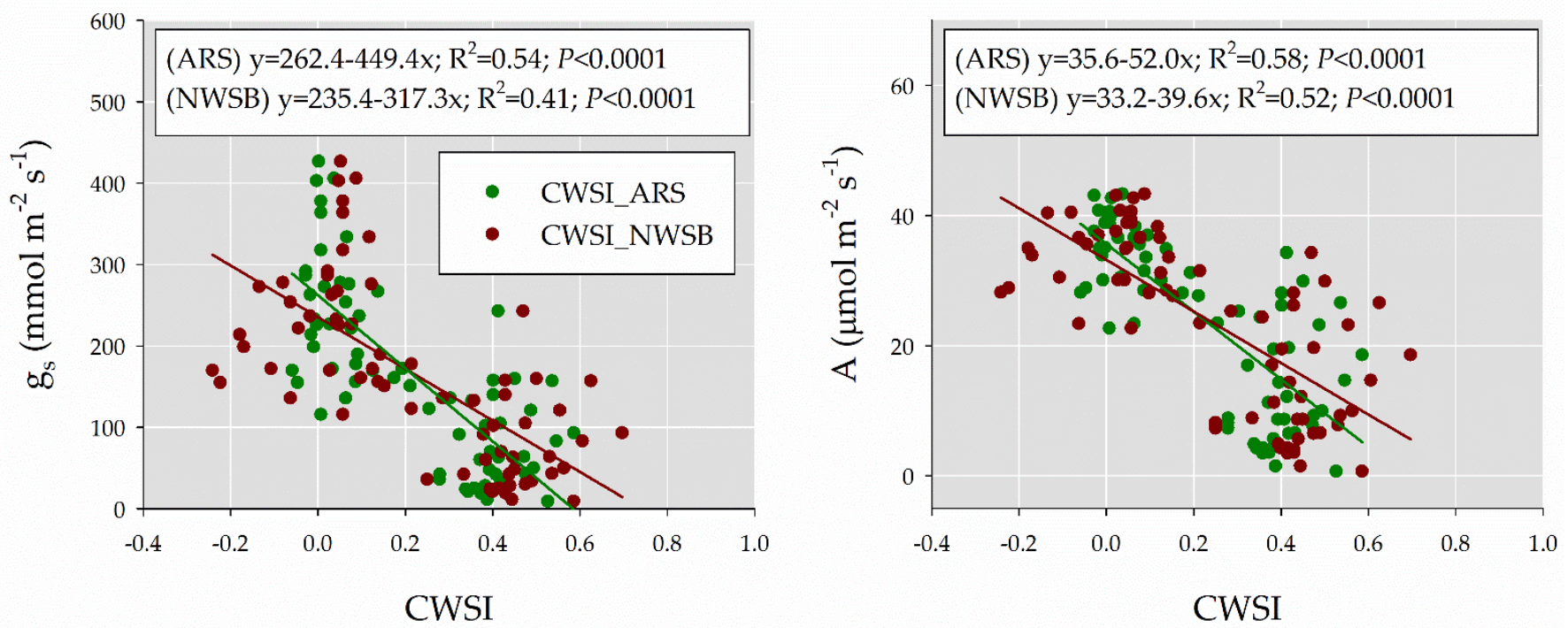

Figure 12. Relationship between stomatal conductance $\left(g_{s}\right)$ (left panel) and leaf photosynthesis (A) (right panel) with ARS-based and NWSB-based crop water stress index (CWSI). In both panels, each point represents a single maize breeding plot and sampling date. The straight lines represent the best-fit regression lines. 


\section{Discussion}

Reference baselines were obtained for the determination of the CWSI in maize under Mediterranean climate conditions. For similar climatic conditions, only the reference baselines obtained in the early 1990s at two locations in Turkey have been found in the literature [28,34]. These lines differed markedly from each other (Table 4), so it was pertinent to obtain newly updated reference baselines for their use in this crop species. The $\mathrm{a}_{\text {pot }}$ values (Equations (2) and (3)) derived at both locations were 1.39 and $2.90{ }^{\circ} \mathrm{C}$, while those obtained in this study varied in the range $2.83{ }^{\circ} \mathrm{C}$ to $5.80^{\circ} \mathrm{C}$ in the time period 10-17 $\mathrm{h}$ (UTC) (Table 5), with $4.16^{\circ} \mathrm{C}$ being the a pot value obtained after analyzing all the data together (Figure 2). Regarding $b_{\text {pot }}$ (Equations (2) and (3)), the values previously obtained in Turkey were -0.86 and $-2.66{ }^{\circ} \mathrm{C} \mathrm{kPa}^{-1}$, whereas the values observed in this study differed significantly since they varied within the range -1.34 to $-1.85^{\circ} \mathrm{C} \mathrm{kPa}^{-1}$ between $10-17 \mathrm{~h}$ (UTC) (Table 5), with $-1.49^{\circ} \mathrm{C} \mathrm{kPa}^{-1}$ being the $\mathrm{b}_{\text {pot }}$ value obtained after analyzing the data together (Figure 2).

The sensitivity of the NWSBs to the changes in climate variables, such as solar radiation and wind speed, has been one of the main criticisms of the method [15] and the reason why these relationships need to be obtained for the local conditions of each climatic region. However, yearly variations in NWSBs obtained at the same location have also been reported in the literature, both for maize [15,32] and other crop species [17]. In our case study, the NWSBs obtained with data from three growing cycles were highly significant, and with coefficients of determination close to 0.9 (Figure 3, Table 5), indicating that the thermal behavior of well-watered maize plants was stable in the long term.

However, the variation in climate variables that occurred between 10-17 h (UTC) did have a significant impact on the reference baselines (Table 5). In most of the works found in the literature that provide reference baselines for CWSI determination in maize, the parameters $\mathrm{a}_{\text {pot }}$ and $\mathrm{b}_{\text {pot }}$ were obtained using data gathered during several daytime hours (Table 4). Only the work carried out by Payero and Irmak [27] took into account the hourly weather variation on the reference baselines by providing equations that included several climate variables as independent variables. The data obtained in our case study confirm that the use of a single reference equation for a relatively large hourly period can lead to inaccurate CWSI estimates (Figure 5).

A common practice for the empirical determination of the CWSI is to use a constant value of $\Delta \mathrm{T}_{d r y}$, often $5{ }^{\circ} \mathrm{C}$ or even lower, as shown in Table 4 . The mean $\Delta \mathrm{T}_{d r y}$ values obtained in this work with Equation (3) showed ample diurnal variation $\left(4.5-8^{\circ} \mathrm{C}\right)$ (Figures 6 and 8), so the use of a fixed $\Delta \mathrm{T}_{d r y}$ value can introduce important sources of error in the determination of the CWSI and must be avoided. Moreover, the $\Delta \mathrm{T}_{d r y}$ values estimated with Equation (3) were rather close to those measured in senescent (non-transpiring) maize plants (Figure 6), validating the suitability of using Equation (3) and not a fixed $\Delta \mathrm{T}_{d r y}$ value for the determination of CWSI. The small difference observed between the measured $\Delta \mathrm{T}_{d r y}$ and $\Delta \mathrm{T}_{d r y}$ estimated with Equation (3) can be explained by the existing differences in the specific heat capacity of fresh and dry leaves [37].

The CWSI values calculated using the reference baselines obtained in this work were sensitive to the irrigation treatments imposed (Figure 7). In 2019, for example, it could be observed how the maize cultivars subjected to flowering stress (WS1) showed decreasing CWSI values once irrigation was restored, whereas the maize cultivars subjected to grainfilling water stress (WS2) showed an increasing trend in CWSI during this phenological period (Figure 7). This pattern was also observed in the measured $\mathrm{g}_{\mathrm{s}}$ and A values (Figure 9). In fact, when all CWSI values determined during the three experimental years were plotted against the leaf gas exchange variables analyzed ( $g_{s}$ and $A$ ), statistically significant relationships were obtained for both variables (Figure 10). In this regard, the relationship between the CWSI and $g_{s}$ presented higher data scattering than that between the CWSI and A, which was especially marked for the lower range of CWSI values (well-watered conditions). The high variability of $g_{s}$, even for similar crop water-status conditions, has already been described in field-grown maize plants $[38,39]$ and is probably 
caused by the large number of factors that influence this physiological variable, such as air temperature, vapor pressure deficit, phenological stage, the degree of sun exposure of leaves or the leaf position within the vertical gradient of the plant [39]. In any case, the high sensitivity of the CWSI index to maize water stress makes it an excellent irrigation-decision tool for environmentally vulnerable or drought-prone areas [40]. The variable $\Delta \mathrm{T}$ has also been proposed on some occasions as a feasible crop water status indicator [41]. The comparison of the $\Delta \mathrm{T}$ values observed in the deficit irrigation treatments (Figure 8) with the patterns of $\mathrm{g}_{\mathrm{s}}$ and $\mathrm{A}$ (Figure 9) confirms the sensitivity of this variable to maize water stress. However, the relationship between $\Delta \mathrm{T}$ with $\mathrm{A}$ and $\mathrm{g}_{\mathrm{s}}$ (not shown) was notably poorer than that observed between $\mathrm{A}$ and $\mathrm{g}_{\mathrm{s}}$ with CWSI (Figure 10), denoting the better performance of CWSI as a predictor of crop water stress level in maize.

Recently, Apolo-Apolo et al. [8] developed two prototypes of artificial reference surfaces (ARSs) for the determination of the CWSI in maize. The ARSs are cellulosebased hemispherical surfaces that determine the temperature of maize plants transpiring at its potential rate $\left(\mathrm{T}_{p o t}\right)$ and that of non-transpiring maize plants $\left(\mathrm{T}_{d r y}\right)$ under the current environmental conditions. Their installation on board HTPP platforms is suitable for the real-time determination of CWSI in maize breeding programs. However, the use of reference baselines instead of ARS could simplify the methodology to monitor CWSI with HTPP platforms in maize breeding programs. In addition to the ARS itself, this methodology also requires two infrared thermometers and a solar radiation sensor, whereas the reference baselines only need air temperature and relative humidity to be monitored. On three dates of the 2018 experimental period, ARS-based and NWSB-based CWSI values were determined and compared (Figure 11). Both methods yielded CWSI values that were highly correlated with leaf gas exchange variables (Figure 12). However, ARS-based CWSI values explained $13 \%$ and $6 \%$ more of the observed variability in $\mathrm{g}_{s}$ and $\mathrm{A}$, respectively, than NWSB-based CWSI. These results suggest that ARS-based CWSI values were slightly more accurate than the NWSB-based CWSI to monitor maize water stress, but the choice of one method or the other will be conditioned more by the level of instrumental complexity desired in the HTPP platform than by the observed differences in accuracy.

However, since the comparison of both methods has been performed exclusively on one growing cycle, a more comprehensive comparison with a larger dataset should be addressed in future experimental work.

\section{Conclusions}

New reference baselines have been determined for the empirical calculation of the CWSI in maize under Mediterranean climate conditions. Since the reliability of the method relies on their long-term stability, this work has shown that the reference lines remained stable for three years but were markedly influenced by meteorological variations between 10-17 h UTC, especially solar radiation. The results obtained justify the use of several reference baselines throughout the day, each one determined for the mean environmental conditions of a particular time of day. The use of a fixed $\Delta \mathrm{T}_{d r y}$ value is not recommended since it also shows a marked diurnal pattern driven by variations in solar radiation. A comparison of the CWSI values determined with the reference baselines and with artificial reference surfaces (ARS) developed in a previous study, shows that the use of ARS can provide slightly more accurate CWSI values for maize water stress monitoring, although it is also a method of greater instrumental complexity.

Author Contributions: Conceptualization, G.E. and A.P.; methodology, A.P., G.E., O.E.A.-A., P.C.-V. and M.P.-R.; software, G.E., O.E.A.-A., A.P.; validation, A.P. and G.E.; formal analysis, G.E. and A.P.; investigation, G.E., A.P., O.E.A.-A., P.C.-V. and M.P.-R.; resources, G.E. and M.P.-R.; data curation, G.E., A.P., P.C.-V. and O.E.A.-A.; writing—original draft preparation, G.E. and A.P.; writing-review and editing, A.P., G.E., O.E.A.-A., P.C.-V. and M.P.-R.; visualization, G.E.; supervision, G.E. and M.P.-R.; project administration, G.E. and M.P.-R.; funding acquisition, G.E. and M.P.-R. All authors have read and agreed to the published version of the manuscript. 
Funding: This research was funded by the Spanish Ministry of Economy and Competitiveness, grant number AGL2016-78964-R. O.E.A.-A. acknowledges the Predoctoral Research Fellowship funded by the University of Seville R + D + I program (IV.3 2017).

Institutional Review Board Statement: Not applicable.

Informed Consent Statement: Not applicable.

Data Availability Statement: Data are presented in the text.

Acknowledgments: The authors would like to thank the company Corteva Agrisciences for the possibility of carrying out the experimental works in the facilities the company has in Seville.

Conflicts of Interest: The authors declare no conflict of interest.

\section{References}

1. Lobell, D.; Hammer, G.; McLean, G.; Messina, C.; Roberts, M.J.; Schlenker, W. The critical role of extreme heat for maize production in the United States. Nat. Clim. Chang. 2013, 3, 497-501. [CrossRef]

2. Ansah, I.G.K.; Oduro, H.; Osae, A.L. A comparative analysis of profit efficiency in maize and cowpea production in the ejura sekyedumase district of the ashanti region, ghana. Res. Appl. Econ. 2014, 6, 106. [CrossRef]

3. Retta, A.; Hanks, R.J. Corn and alfalfa production as influenced by limited irrigation. Irrig. Sci. 1980, 1, 135. [CrossRef]

4. Stegman, E.C. Corn grain yield as influenced by timing of evapotranspiration deficits. Irrig. Sci. 1982, 3, 75-87. [CrossRef]

5. Fereres, E.; Soriano, M.A. Deficit irrigation for reducing agricultural water use. J. Exp. Bot. 2007, 58, 147-159. [CrossRef]

6. DeJonge, K.C.; Taghvaeian, S.; Trout, T.J.; Comas, L. Comparison of canopy temperature-based water stress indices for maize. Agric. Water Manag. 2015, 156, 51-62. [CrossRef]

7. Araus, J.L.; Slafer, G.; Royo, C.; Serret, M.D. Breeding for yield potential and stress adaptation in cereals. Crit. Rev. Plant Sci. 2008, 27, 377-412. [CrossRef]

8. Apolo-Apolo, O.; Martínez-Guanter, J.; Pérez-Ruiz, M.; Egea, G. Design and assessment of new artificial reference surfaces for real time monitoring of crop water stress index in maize. Agric. Water Manag. 2020, 240, 106304. [CrossRef]

9. Zia, S.; Romano, G.; Spreer, W.; Sanchez, C.; Cairns, J.; Araus, J.L.; Müller, J. infrared thermal imaging as a rapid tool for identifying water-stress tolerant maize genotypes of different phenology. J. Agron. Crop. Sci. 2012, 199, 75-84. [CrossRef]

10. Maes, W.H.; Steppe, K. Estimating evapotranspiration and drought stress with ground-based thermal remote sensing in agriculture: A review. J. Exp. Bot. 2012, 63, 4671-4712. [CrossRef] [PubMed]

11. Jackson, R.D.; Idso, S.B.; Reginato, R.J.; Pinter, P.J., Jr. Canopy temperature as a crop water stress indicator. Water Resour. Res. 1981, 17, 1133-1138. [CrossRef]

12. Idso, S.B. Non-water-stressed baselines: A key to measuring and interpreting plant water stress. Agric. Meteorol. 1982, 27, 59-70. [CrossRef]

13. Bellvert, J.; Marsal, J.; Girona, J.; Gonzalez-Dugo, V.; Fereres, E.; Ustin, S.L.; Zarco-Tejada, P.J. Airborne thermal imagery to detect the seasonal evolution of crop water status in peach, nectarine and saturn peach orchards. Remote Sens. 2016, 8, 39. [CrossRef]

14. Egea, G.; Padilla-Díaz, C.M.; Martinez-Guanter, J.; Fernández, J.E.; Pérez-Ruiz, M. Assessing a crop water stress index derived from aerial thermal imaging and infrared thermometry in super-high density olive orchards. Agric. Water Manag. 2017, 187, 210-221. [CrossRef]

15. Han, M.; Zhang, H.; DeJonge, K.C.; Comas, L.H.; Gleason, S. Comparison of three crop water stress index models with sap flow measurements in maize. Agric. Water Manag. 2018, 203, 366-375. [CrossRef]

16. Khorsand, A.; Rezaverdinejad, V.; Asgarzadeh, H.; Majnooni-Heris, A.; Rahimi, A.; Besharat, S. Irrigation scheduling of maize based on plant and soil indices with surface drip irrigation subjected to different irrigation regimes. Agric. Water Manag. 2019, 224, 105740. [CrossRef]

17. Gonzalez-Dugo, V.; Zarco-Tejada, P.J.; Fereres, E. Applicability and limitations of using the crop water stress index as an indicator of water deficits in citrus orchards. Agric. For. Meteorol. 2014, 198-199, 94-104. [CrossRef]

18. Idso, S.; Jackson, R.; Pinter, P.; Reginato, R.; Hatfield, J. Normalizing the stress-degree-day parameter for environmental variability. Agric. Meteorol. 1981, 24, 45-55. [CrossRef]

19. Ben-Gal, A.; Agam, N.; Alchanatis, V.; Cohen, Y.; Yermiyahu, U.; Zipori, I.; Presnov, E.; Sprintsin, M.; Dag, A. Evaluating water stress in irrigated olives: Correlation of soil water status, tree water status, and thermal imagery. Irrig. Sci. 2009, 27, 367-376. [CrossRef]

20. Alchanatis, V.; Cohen, Y.; Cohen, S.; Moller, M.; Sprinstin, M.; Meron, M.; Tsipris, J.; Saranga, Y.; Sela, E. Evaluation of different approaches for estimating and mapping crop water status in cotton with thermal imaging. Precis. Agric. 2010, 11, 27-41. [CrossRef]

21. Maes, W.H.; Baert, A.; Huete, A.; Minchin, P.E.; Snelgar, W.P.; Steppe, K. A new wet reference target method for continuous infrared thermography of vegetations. Agric. For. Meteorol. 2016, 226-227, 119-131. [CrossRef]

22. Andrade-Sanchez, P.; Gore, M.; Heun, J.T.; Thorp, K.; Carmo-Silva, E.; French, A.; Salvucci, M.E.; White, J.W. Development and evaluation of a field-based high-throughput phenotyping platform. Funct. Plant Biol. 2014, 41, 68-79. [CrossRef] 
23. Taghvaeian, S.; Chávez, J.L.; Bausch, W.C.; DeJonge, K.C.; Trout, T.J. Minimizing instrumentation requirement for estimating crop water stress index and transpiration of maize. Irrig. Sci. 2014, 32, 53-65. [CrossRef]

24. Taghvaeian, S.; Chávez, J.; Hansen, N.C. infrared thermometry to estimate crop water stress index and water use of irrigated maize in Northeastern Colorado. Remote Sens. 2012, 4, 3619-3637. [CrossRef]

25. Zhang, L.; Zhang, H.; Niu, Y.; Han, W. Mapping maize water stress based on UAV multispectral remote sensing. Remote Sens. 2019, 11, 605. [CrossRef]

26. Cárcova, J.; Maddonni, G.; Ghersa, C. Crop water stress index of three maize hybrids grown in soils with different quality. Field Crop. Res. 1998, 55, 165-174. [CrossRef]

27. Payero, J.O.; Irmak, S. Variable upper and lower crop water stress index baselines for corn and soybean. Irrig. Sci. 2006, 25, 21-32. [CrossRef]

28. Irmak, S.; Haman, D.Z.; Bastug, R. Determination of crop water stress index for irrigation timing and yield estimation of corn. Agron. J. 2000, 92, 1221-1227. [CrossRef]

29. Steele, D.D.; Stegman, E.C.; Gregor, B.L. Field comparison of irrigation scheduling methods for corn. Trans. ASAE 1994, 37, 1197-1203. [CrossRef]

30. Nielsen, D.C.; Gardner, B.R. Scheduling irrigations for corn with the crop water stress index (CWSI). Appl. Agric. Res. 1987, 2, 295-300.

31. Kar, G.; Kumar, A. Energy balance and crop water stress in winter maize under phenology-based irrigation scheduling. Irrig. Sci. 2010, 28, 211-220. [CrossRef]

32. Li, M.; Chu, R.; Yu, Q.; Islam, A.R.M.T.; Chou, S.; Shen, S. Evaluating structural, chlorophyll-based and photochemical indices to detect summer maize responses to continuous water stress. Water 2018, 10, 500. [CrossRef]

33. Mangus, D.L.; Sharda, A.; Zhang, N. Development and evaluation of thermal infrared imaging system for high spatial and temporal resolution crop water stress monitoring of corn within a greenhouse. Comput. Electron. Agric. 2016, 121, 149-159. [CrossRef]

34. Gençğlan, C.; Yazar, A. Determination of crop water stress index (CWSI) and irrigation timing by utilizing infrared thermometer values on the first corn grown under çukurova conditions. Turk. J. Agric. For. 1999, 23, 87-95. [CrossRef]

35. Allen, R.G.; Pereira, L.S.; Raes, D.; Smith, M. Crop Evapotranspiration. FAO Irrigation and Drainage Paper No 56; FAO, Ed.; FAO: Rome, Italy, 1998.

36. Fattahi, K.; Babazadeh, H.; Najafi, P.; Sedghi, H. Scheduling maize irrigation based on crop water stress index (CWSI). Appl. Ecol. Environ. Res. 2018, 16, 7535-7549. [CrossRef]

37. Michaletz, S.T.; Weiser, M.D.; Zhou, J.; Kaspari, M.; Helliker, B.R.; Enquist, B. Plant thermoregulation: Energetics, trait environment interactions, and carbon economics. Trends Ecol. Evol. 2015, 30, 714-724. [CrossRef]

38. Yu, G.-R.; Nakayama, K.; Lu, H.-Q. Responses of stomatal conductance in field-grown maize leaves to certain environmental factors over a long term. J. Agric. Meteorol. 1996, 52, 311-320. [CrossRef]

39. Rochette, P.; Pattey, E.; Desjardins, R.; Dwyer, L.; Stewart, D.; Dubé, P. Estimation of maize (Zea mays L.) canopy conductance by scaling up leaf stomatal conductance. Agric. For. Meteorol. 1991, 54, 241-261. [CrossRef]

40. Bournaris, T.; Papathanasiou, J.; Manos, B.; Kazakis, N.; Voudouris, K. Support of irrigation water use and eco-friendly decision process in agricultural production planning. Oper. Res. 2015, 15, 289-306. [CrossRef]

41. García-Tejero, I.F.; Zuazo, V.H.D.; Arriaga, J.; Hernández, A.; Vélez, L.M.; Muriel-Fernández, J.L. Approach to assess infrared thermal imaging of almond trees under water-stress conditions. Fruits 2012, 67, 463-474. [CrossRef] 